\title{
E-278 - ORDENS RÉGIAS 1681-1809. Um códice do Arquivo da Cúria Metropolitana do Rio de Janeiro
}

Beatriz Catão Cruz Santos*

\section{RESUMO}

Este trabalho é um instrumento de pesquisa que apresenta o livro ou códice $E-278$ - Ordens Régias 1681-1809, localizado no Arquivo da Cúria Metropolitana do Rio de Janeiro. Contém um índice de ordens, alvarás e cartas reunidas sob a rubrica "ordens régias", expedidas em nome do soberano e transmitidas ao bispado do Rio de Janeiro entre 1681 e 1809. Acompanha o índice uma introdução sobre a documentação e um panorama dos assuntos tratados. O trabalho é um dos resultados da pesquisa Irmandades, Capelas e Rituais no Rio de Janeiro do século XVIII, desenvolvida na Universidade Federal do Rio de Janeiro. A publicação do referido códice, entre três que a pesquisa selecionou, é importante para a história do Rio de Janeiro no Antigo Regime e sua inserção no império português.

Palavras-chave: ordens régias; códice; bispado, Antigo Regime, império português.

\section{ABSTRACT}

This paper is a research instrument presenting the codex E-278 - Ordens Régias 1681-1809, from the archives of the Rio de Janeiro Metropolitan Curia. Preceded by an introduction about the documentation, and an overview of the contents, the core of the work consists in an index of decrees, charters, and letters sent on behalf of the King of Portugal to the Bishop of Rio de Janeiro between 1681 and 1809. It is part of a larger research project of the Federal University of Rio de Janeiro - Brotherhoods, Chapels and Rituals in Eighteenth-Century Rio de Janeiro - that selected three codices for publication and further historical research on the role of Rio in the Portuguese Empire during the Ancient Regime.

Keywords: royal decree; codex; bishop; Old Regime; Portuguese Empire. 
Em 2010 decidi elaborar alguns índices relativos a três códices existentes no Arquivo da Cúria Metropolitana do Rio de Janeiro (E-278 - Ordens Régias 1681-1809; E-236 — Pastorais e Editais. Livro 1. 1742-1838; Códice E-279 - Ordens Régias. Livro 2. 1809-1862). A decisão adveio de uma identificação anterior de documentos relativos à festa de Corpus Christi no códice 236, ${ }^{1}$ que não consultei na época de doutorado ${ }^{2}$ e, sobretudo, porque estava contando com o método que costumamos chamar "agulha no palheiro". Ou seja, na ausência de catálogos detalhados, geralmente contamos só com a experiência dos funcionários dos arquivos. Consequentemente, localizar um documento adequado depende muito da sorte. Nesse caso, sou grata a Silvia Regina de A. Souza, Marcia Regina de Mello Freire e Paulo Lavandeira Fernandes, que me informaram sobre o potencial dos referidos códices para o estudo do culto católico no bispado do Rio de Janeiro. Portanto, além do trabalho de transcrição de alguns documentos que interessavam especificamente à pesquisa Irmandades, Capelas e Rituais no Rio de Janeiro do século XVIII, que coordeno na Universidade Federal do Rio de Janeiro, comecei a elaborar listas dos documentos que constavam dos códices, seguindo a ordem dos mesmos.

De acordo com Silvia Souza, esses livros (236, 278 e 279) estiveram desde sempre na Cúria, advindo da antiga Câmara Eclesiástica. Náo há informaçóes sobre o momento de confecção da brochura, que reúne documentos avulsos de natureza variada.

A relevância desses documentos para a história do bispado do Rio de Janeiro, assim como do império português é inegável. Isto é perceptível não somente pelo recuo no tempo, que dá acesso à regulamentação da vida religiosa até o século XVII, como na extensão geográfica, porque transcende os limites do que fora o bispado do Rio de Janeiro no século XVIII. ${ }^{3}$ Em 1745, o bispado do Rio de Janeiro compreendia o que hoje constitui os estados do Rio de Janeiro, de São Paulo, de Minas Gerais, de Goiás, do Mato Grosso, do Paraná, de Santa Catarina, do Rio Grande do Sul e ainda incluía a Colônia do Sacramento. ${ }^{4}$

\footnotetext{
${ }^{1}$ Passarei a denominar os códices ou livros do Arquivo da Cúria Metropolitana do Rio de Janeiro (ACMRJ) apenas pelo número para simplificar a referência.

${ }^{2} \mathrm{Na}$ época do doutorado o Arquivo da Cúria Metropolitana do Rio de Janeiro estava fechado. Dele resultou o livro SANTOS, Beatriz Catão Cruz. O Corpo de Deus na América; a procissão de Corpus Christi nas cidades da América portuguesa — século XVIII. São Paulo: Annablume, 2005.

${ }^{3}$ Em 1575 foi criada a prelazia do Rio de Janeiro. Um século depois, por intermédio da bula Romani Pontificis pastoralis sollicitudo (1676), a prelazia foi elevada a bispado de São Sebastiáo do Rio de Janeiro, sufragâneo da Bahia, que no mesmo ano torna-se arquidiocese. O bispado do Rio de Janeiro só se tornaria arquidiocese em 1892. HOLANDA, Sérgio Buarque de Holanda (Dir.). História geral da civilização brasileira. t. I (A época Colonial). São Paulo: Difel, 1985. p. 51-87; Para mais informaçôes ver: <http://arqrio.org/a-arquidiocese/ nossa-historia>. Acesso em: 26 mar. 2015. Sobre os bispos, uma boa obra de referência: PAIVA, José Pedro. Os bispos de Portugal e do Império. 1495-1777. Coimbra: Universidade de Coimbra, 2006.

${ }^{4}$ É possível consultar o mapa "Os bispados do Brasil na época de criaçáo de novas dioceses" (1745) em: RUBERT, Arlindo. A Igreja no Brasil. Expansão territorial e absolutismo estatal (1700-1822). V. III. Santa Maria: Palotti, 1988. Veja o documento que inclui na jurisdição do bispado a área desde o sul do Rio São Francisco até a Colônia do Sacramento: doc. 417, f. 187.
} 
Além disso, é sabido da dificuldade, hoje relativa, do acesso à documentação no período do Antigo Regime. É com satisfaçáo que torno pública — com o auxílio dos bolsistas que tive até agora, sem os quais seria inviável tornar público aos pesquisadores — a listagem do 278. ${ }^{5}$ Até o momento a lista só circulava entre meus alunos e no arquivo, acompanhando os novos investigadores que se aventurassem a consultar os códices. A expectativa é que num futuro próximo possamos publicar as listas relativas aos outros códices. A escolha do 278 como o primeiro a ser publicado foi, sob certos aspectos, circunstancial, advinda do movimento do trabalho, das idas e vindas do restauro, entre outros aspectos, que marcam o dia a dia de um arquivo.

Pode-se ter uma indicaçáo da variedade temática destes códices e, em particular, do 278, através de uma seleção entre as chamadas "Ordens Régias", rubrica que reúne ordens régias, alvarás, cartas, petiçôes, certidóes etc. As "Ordens Régias" são expedidas em nome do soberano e dirigidas, em primeira instância, ao bispado. ${ }^{6}$ Foram selecionados apenas alguns temas, a partir de uma leitura geral. Portanto, o levantamento não é completo e sugere-se ao pesquisador que faça uma leitura transversal da lista pinçando os documentos que mais despertem seu interesse.

No códice 278 destacam-se os ritos que envolvem os sacramentos - como o batismo, a eucaristia, a penitência, o matrimônio e a ordem - e as celebraçóes régias - nascimento e morte. ${ }^{7}$ No campo dos ritos, há temas específicos, como a ordem que regulamenta as cadeiras a serem alocadas nas missas em Angola, que deveriam seguir o ritual romano. ${ }^{8}$ É interessante observar que os ritos referidos dizem respeito a diferentes localidades do império: Rio de Janeiro, Minas Gerais, São Paulo, Maranhão e, como indicado, Angola. Com relação aos sacramentos, é interessante observar a sua administração a diferentes grupos sociais, como é o caso dos escravos e dos soldados das fortalezas. ${ }^{9}$

A documentação desse códice também contribui para a história administrativa do bispado. Ela informa sobre novas circunscriçóes eclesiásticas, a exemplo da divisão Sé e da Candelária em quatro paróquias ocorrida em 1749, a criação da Freguesia de São João, que desanexa as povoaçôes de Botafogo, Praia Vermelha e Tijuca da antiga Freguesia de São José, e a criação de vigararias coladas como a Igreja de São Sebastiâo de Itaipu, do bispado

\footnotetext{
${ }^{5}$ Sou grata a vários alunos que trabalharam neste projeto, em particular a Anna Beatriz Meireles Tomaz Sarcedo Dias, Mayara Novaes Valverde e Laís Morgado Marcoje.

${ }^{6}$ Algumas referências para pensar as "Ordens Régias" foram extraídas de BELLOTO, Heloísa Liberalli. Como fazer análise diplomática e análise tipológica. Como fazer. Arquivo do Estado e Imprensa Oficial do Estado, São Paulo, v. 8, p. 79, 2002. Disponível em: <http://www.arqsp.org.br/arquivos/oficinas_colecao_ como_fazer/cf8.pdf>. Acesso em: 26 mar. 2015.

7 Para consultar os títulos dos documentos, seguem sua numeraçáo e página respectiva do livro. V indica o verso da página. doc. 48, f. 23-23v; doc. 48, f. 23-23v, doc. 60, f. 29; doc. 73, f. 33v; doc. 95, f. 42v.

${ }^{8}$ Doc. 453 , f. $198 \mathrm{v}$.

${ }^{9}$ Doc. 406, f. $181 \mathrm{v}$.
} 
do Rio de Janeiro. ${ }^{10}$ Também é possível ter acesso às côngruas e emolumentos pagos aos funcionários dos bispados, assim como à circulação de riquezas no império por diversos motivos, incluindo religiosos. ${ }^{11}$ A documentação contribui para uma história administrativa renovada pela ação governativa dos bispos, que se expressa nas visitas paroquiais, no recenseamento das igrejas do Recôncavo da Guanabara, das Minas e do conjunto do bispado. ${ }^{12}$ Há também várias ordens régias que solicitam aos bispos informaçóes populacionais. Um censo demográfico, que classifica a população em brancos/escravos; homens/mulheres; casados/ solteiros; adultos/crianças. ${ }^{13} \mathrm{O}$ primeiro critério sinaliza para a particularidade da escravidão moderna, de africanos e seus descendentes. A história da Sé também ganha com vários documentos, que informam sobre o tempo em que ela esteve interina (1707-1808) após a saída da Igreja de Sáo Sebastião no Morro do Castelo em direção à várzea. ${ }^{14}$ Interessante será relembrar os critérios diversos, incluindo a limpeza de sangue necessária às dignidades e cônegos da Sé que vigoravam no século XVII. ${ }^{15}$

No códice 278 também é possível encontrar várias informações sobre o regime escravista: ordens acerca do tratamento dos escravos ${ }^{16} \mathrm{e}$, sobretudo, a respeito da administraçáo dos sacramentos a esta parcela representativa do bispado. ${ }^{17}$

Destacam-se também os documentos que informam sobre diferentes modalidades de conflitos ocorridos na circunscrição: entre vigário e seus fregueses, entre membros das câmaras municipais e párocos, entre regulares e o bispo e entre vigário da Vara e juiz ordinário acerca de clérigos que tinham tavernas. ${ }^{18}$

Há que se mencionar a presença de vários documentos sobre as missóes indígenas, ${ }^{19} \mathrm{a}$ Junta Geral das Missóes ${ }^{20}$ e a extinção da Companhia de Jesus. ${ }^{21}$ Por fim, não se pode deixar de sublinhar a forte presença da região das Minas neste códice, que atravessa temas arrola-

${ }^{10}$ Doc. 411, f. $184 v$; doc. 544 , f. $263 \mathrm{v}-263$; doc. 467, f. 203v-205. No caso de novas vigararias coladas há os documentos sequenciais de 468 a 479.

${ }^{11}$ Transferências de esmolas do bispado e, particularmente, das Minas, para instituiçóes religiosas de Lisboa, do Porto e de Goa (doc. 213, f. 98; doc. 233, f. 105v-106; doc. 241, f. 108v; doc. 394, f. 177-177v), assim como contribuições para celebraçôes régias extraordinárias (doc. 276, f. 123v).

${ }^{12}$ Doc. 7, f. 4-4v; doc. 430, f. 189; doc. 346, f. 156v-157; doc. 72, f. 33-33v e doc. 340, f. $153 \mathrm{v}$.

${ }^{13}$ Doc. 111, f. 50v-51; doc. 123, f. 56v-57; doc. 216, f. 99. Nesta documentação, crianças são as que não recebem sacramentos.

${ }^{14}$ Doc. 352 , f. $159 \mathrm{v}-160$, entre outros.

${ }^{15}$ Doc. 6, f. $3 \mathrm{v}-4$

${ }^{16}$ Doc. 10, f. $5 \mathrm{v}-6$.

${ }^{17}$ Doc. 119 , f. $54 \mathrm{v}-55$ e doc. 130 , f. $60 \mathrm{v}-61 \mathrm{v}$.

${ }^{18}$ Doc. 533, f. 257-258 ; doc. 183, f. 85.

${ }^{19}$ Doc. 289, f. 128v; doc. 332, f. 148v-149.

${ }^{20}$ Doc. 25 , f. 13v-14; doc. 31, f. 16v; doc. 32, f. 16v-17; doc. 447, f. 197. Na documentação é referida como Junta das missóes. Sobre o organismo, criado em cerca de 1655, também denominado Junta dos Missionários ou Junta para a propagação da fé: MELLO, Marcia Eliane A. Souza e. Entre Conselhos e Tribunais Régios: a Junta Geral das Missóes no Antigo Regime português. Portuguese Studies Review, v. 17, p. 61-91, 2012.

${ }^{21}$ Doc. 513, f. 228v-229, doc. 514, f. 229-231, doc. 515, f. 231v-245. 
dos nesta introduçãa. Como já foi observado, os assuntos são diversos, incluem ainda mal comportamento de religiosos ${ }^{22}$ e o controle para evitar a evasão de mulheres para Portugal. ${ }^{23}$

\section{Aspectos formais}

É importante observar certos aspectos formais dos títulos dos documentos que constam do 278. Como é costumeiro na época, há uma enorme variedade de grafias no interior do códice, que mantivemos como no original. Por isso, selecionamos os exemplos, localizados nos respectivos documentos. São eles: conhecença (doc. 116), conhecencias (doc. 117) e conhecenssaz (doc. 223); Vagante (doc. 3) e vacante (docs. 16, 184, 376, 511 e 537); Pernagua (doc. 14) e Pernaguá (doc. 37); asougue (doc. 26) aSouge (doc. 437); Gurgel (doc. 71) e Grugel (doc. 82); dimisoriaz (doc. 154) e Dimisurias (doc. 164); aljubi (doc. 167) e aljube (docs. 377, 390 e 522), emolumentos (doc. 211) e emuLimentos (doc. 333); Paracis (doc. 332) e o plural Paracizes (doc. 334), cleregos (doc. 354) e clerigos (docs. 286, 306, 359 e 436), Conssiencia (doc. 407) e Consciencia (docs. 230, 314, 496, 497, 539); Eucesos (doc. 494) e excessos (docs. 10 e 336); Deiáo (doc. 501) e deão (docs. 1, 17, 162, 318, 321, 408 e 480). Há também grafias singulares, que não se pode assegurar serem erros, omissóes, costume ou decorrência de um letramento falho. São os casos de Nomer (doc. 173), copor (doc. 198), aRematação (doc. 375), falssas (doc. 432). Em todos os casos, mantivemos o repeito ao documento.

Além disso, há que mencionar outras características do códice que afetam a paginação: há duas folhas 163. A numeração das páginas está fora de ordem, pois a folha 188 antecede a 187, depois da folha 187 há a 184, depois da folha 202 há a 204, depois da folha 204 há a 203, depois da folha 222 há a 224, não há a folha 230 e a folha 263 é repetida.

Por fim, é importante mencionar que, na elaboração desse instrumento de pesquisa, foram usadas as Normas técnicas para transcrição e edição de documentos manuscritos ${ }^{24} \mathrm{de}$ acordo com a Comissão de Sistematização e Redação do I Encontro Nacional de Normatização Paleográfica (São Paulo: 28 e 29 de novembro de 1990) e do II Encontro Nacional de Normatização Paleográfica (São Paulo: 16 e 17 de setembro de 1993). A partir daquelas normas, que visam unificar as ediçôes paleográficas, usamos as seguintes:

Respeito total ao documento.

O S caudado duplo será transcrito como SS e o simples como $S$.

O R e $S$ maiúsculos, com som de rr e ss serão transcritos $R$ e $S$ maiúsculos, respectivamente.

\footnotetext{
${ }^{22}$ Doc. 85 , f. 38-38v; doc. 115, f. 52-52v; doc. 124, f. 57-57v; doc. 126, f. 58.

${ }^{23}$ Doc. 340, f. 153v; doc. 351; f. 158v-159v.

${ }^{24}$ Para ter acesso a essas normas pode-se consultar: $<$ http://www.arquivonacional.gov.br/Media/Transcreve. pdf $>$. Acesso em: 22 mar. 2015.
} 
As letras ramistas b, v, u, i, j serão mantidas como no manuscrito.

Aos enganos, omissóes, repetiçóes e truncamentos que comprometam a compreensão do texto recomenda-se o uso da palavra latina [sic] entre colchetes e grifada.

Todas as abreviaturas serão desdobradas.

Os sinais especiais de origem latina e os símbolos e palavras monogramáticas serão desdobrados, por exemplo, \& $\mathrm{r}^{\mathrm{a}}=$ etc.; IHR = Christus.

Os sinais de restos de taquigrafia e notas tironianas serão vertidos para a forma que representam, grifados.

O sinal de nasalização ou til, quando com valor de m ou n, será desdobrado.

Quando a leitura paleográfica de uma palavra for duvidosa, colocar-se-á uma interrogação entre colchetes depois da mesma: [?].

As maiúsculas e minúsculas serão mantidas.

A ortografia será mantida na íntegra, não se efetuando nenhuma correção gramatical.

As palavras que se apresentam parcial ou totalmente ilegíveis, mas cujo sentido textual permita a sua reconstituição, serão impressas entre colchetes.

As palavras ilegíveis para o transcritor serão indicadas com a palavra ilegível entre colchetes e grifada: [ilegivel].

A seguir, os documentos que constam do Códice 278:

1) Lixboa 18 de Novembro de 1681 Ordem em que Se manda pagar do Contrato das Baleias as Congruas ao Senhor Bispo de 800 mil réis para esmollas 800 mil réis e para Seus officiaes 120 mil réis ao Reverendo Deão 100 mil réis, a cada huma das quatro dignidades 80 mil réis, e a cada hum dos Seis Conegos 60 mil réis e cada hum dos douz mayor Conegos 30 mil réis a cada hum dos quatro Capelaes 25 mil réis: a hum cura que Se há de prover annual 7309.20 réis, a hum Coadjutor 25 mil réis a cada hum dos quatro mossos do Couro 12 mil réis ao Mestre da Capella: 40 mil réis ao Tangedor do orgam 25 mil réis ao Subechantre 20 mil réis ao Porteiro da Mesma 10 mil réis, e da ordinaria da fabrica 120 mil réis a hum Sachristão 25 mil réis [f. 1-1v]

2) Lixboa 16 de Janeiro de 1682 Ordem em que Se manda que oz prezos Eccleziasticos Se Recolhão a Cadea publica desta Cidade [f. 1v-2]

3) Lixboa 11 de Agosto de 1682 Ordem em que Se manda que as côngruas dos Bispos durante a Sé Vagante Se Repartão em trez partes, huma para o gasto das Bullas e ajudas de custo do Bispado futuro, outra para as obras da Igreja, e a outra para o Bispado futuro compor Sua vara com o dever [tendo] que a primeira parte Se retirará do monte mayor e da que Restar Se fação as duaz [f. 2-2v]

4) Lixboa 27 de Janeiro de 1687 Ordem em que Sua Magestade não [corroído $25 \mathrm{~mm} x$ $10 \mathrm{~mm}$ ] ao Requerimento do Senhor Bispo, Sobre apagarsse a Congrua aos Respeitoz pro- 
vidor em Providor [sic] em Dignidadez e Conesias da Se desde o tempo em que chegarão a esta Cidade e Senão Collarão por andar o Senhor Bispo em Vezita porque os podia mandar Collar pellos Seus Ministroz. [f. 2v-3]

5) Lixboa $1^{\circ}$ de Março de 1687 Ordem em que Sua Magestade ordena que o Prelado de qualquer Convento que tiver dos Sacerdotes Mande todos os annos dous a doutrinar e administrar-lhe os Sacramentos: sem prejuízo dos direitos Parochiais [f. 3-3v]

6) Lixboa 15 de Junho de 1687 Ordem que por Rezoluçáo de Sua Alteza em que ordena aos officiaes da Camera da Capitânia do Rio de Janeiro para Serem os naturaes [corroído $10 \mathrm{~mm} \times 10 \mathrm{~mm}$ ] [ilegivel] nos Provimentos que Se fizerem de dignidades e Conegos da nova Sé não Se offerecendo ou por Sugeitos de mayores merecimentos e tendo elles a Limpeza de Sangue e mais circunstancias necessárias [f. 3v-4]

7) Lixboa 4 de Novembro de 1687 Ordem porque Sua Magestade houve por bem que o Senhor Bispo Dom Jozé de Barros Alarção Se desse embarcação todas as vezes que houvesse de hir vizitar as Igrejas de Seu Bispado, ou ao Vigário Geral, ou a outras quaes quer pessoas que elle enviar, e os mantimentos necessarios para a viagem assim como Se dáo aos Bispadoz do Brazil [f. 4-4v]

8) Lixboa 15 de Novembro de 1687 Ordem em que Sua Magestade manda Se pague ao [Priorte] da Sé a quantia de 360.800 réis para a Semana Santa [f. 4v-5]

9) Lixboa 30 de Dezembro de 1687 Ordem em que Sua Magestade Recomenda ao Senhor Bispo lhe de conta do Progresso da Cristandade nestas Conquistas, e applique todos o cuidado a dito Progresso e os Religiozos [f. 5-5v]

10) Lixboa 23 de Março de 1688 Ordem em que Sua Magestade manda moderar os excessos dos castigos aos escravos [f. 5v-6]

11) 27 de Março de 1688 Ordem em que Sua Magestade manda que não Sahão deste Porto Navios Sem Capelaens e que o Senhor Bispo ajustem o que lhe devem pagar os Mestres e que por Sua conta fique o persuadir os Capelaens a hirem, e [pela] do Senhor Governador de obrigar os Mesmos lhe paguem, e que os navios que primeiro partirem deste Porto para Angola Sejâo obrigados a levarem os Capelaens que tiverem de Lá vindo, dandosse lhe a passagem livre, e mantimentos por conta dos mesmos mestres [f. 6-6v]

12) Lixboa 8 de Janeiro de 1689 Ordem em que Sua Magestade manda informar o Senhor Bispo sobre huma queixa que fes a Camera de o dito Prelado impidir Se fizesse a Procissão do Corpo de Deus por falta de sera [f. 6v-7v] -

13) Lixboa 17 de Março de 1693 Ordem Sobre os Escravos de Se lhe não administrarem oz Sacramentos por quererem de conhesenssa mais do que hé devido, em que Elrey encomenda Se tire o excesso, e Se castiguem os Senhores que forem culpados doz ditos escravos não Receberem os Sacramentoz. [f. 7v-8]

14) Lixboa 19 de Novembro de 1700 Sobre a Igreja de Pernagua Se por em Concursso - Copia - [f. 8] 
15) Lixboa 7 de Dezembro de 1701 Ordem em que Sua Magestade ordena o Senhor Bispo para que os Seus Vizitadores Senão entrometão a tomar Conta das Capellas que forem instituidas por leigos e aos Juizes ordinarioz que Se abstenhão dos procedimentos de que cezão [f. 8v]

16) Lixboa 21 de Dezembro de 1701 Ordem em que Sua Magestade manda ao Provedor da Fasenda Real do Rio de Janeiro que na forma da que passou em 11 de Agosto de 682, fassa entregar ao Senhor Bispo Dom Francisco de São Jeronimo a parte que lhe [ilegivel] da Congrua do Bispado daquella Capitania vencida no passado próximo passado [sic] da Sé Vacante [f. 8v-9]

17) Lixboa 26 de Janeiro de 1702 Alvará que Sua Majestade houve por bem de Conceder faculdade ao Senhor Bispo do Rio de Janeiro para poder nomear as dignidades Conesias Vigarios e mais benefícios e cargos ecclesiasticoz daquelle Bispado, depois de nelle Residir e vagarem depois de sua Residencia nas pesoas que lhe parecer excepto a de Deão [f. 9-10]

18) Lixboa 07 de Janeiro de 1702 Ordem que Sua Majestade manda que ao Senhor Bispo se dem os mesmos Cento e vinte mil réis cada anno para a aposentadoria de casas que se derão ao Bispo pelo seu antecessor [f. 10v-11]

19) Lixboa 17 de Fevereiro de 1702 Ordem em que Sua Majestade manda que ao Senhor Bispo Se fassa pagamento de seu ordenado e mantimento de hum Conto de Reiz cada anno [f. 11-11v]

20) Lixboa 10 de Março de 1702 Ordem em que Sua Majestade manda por a Concursso a Igreja de Sáo Salvador deste Bispado por dezistencia do padre Thomás da Fonseca [f. 11v-12]

21) Lixboa 17 de Marco de 1702 Ordem Sobre Se unirem as duas Provincias do Carmo de Brazil a de Portugal. [f. 12-12v]

22) Lixboa 22 de Março de 1702 Ordem em que Sua Majestade manda informar Sobre oporemsse a concursso as Igrejas nas Capitanias do Sul perante o Vigário da vara [f. 12v-13]

23) Lixboa 22 de Março de 1702 Ordem em que Se Recomendão as missóens [f. 13]

24) Lixboa 21 de Abril de 1702 Ordem Sobre os Índios pedidos do Maranhão mandada ao Senhor Bispo [f. 13-13v]

25) Lixboa 21 de Abril de 1702. Ordem Sobre os índios pedidos pelo Maranhão mandada a junta das Missóens [f. 13v-14]

26) Lixboa 10 de Fevereiro de 1703 Carta de Sua Majestade Escrita ao Governador Sobre o asougue do Eclesiastico [f. 14-14v]

27) Lixboa 16 de Fevereiro de 1703 Ordem em Resposta da carta do Senhor Bispo em que Reprezentava a Sua Majestade o escândalo da desnudez Com que Saltavão os escravoz dos Navios [f. 14v]

28) Lixboa 22 de Fevereiro de 1703 Ordem em que Sua Magestade manda approvar a opinião do Senhor Bispo de não hirem Religiosos as missoenz das Minaz [f. 15] 
29) Lixboa 27 de Abril de 1703 Ordem em que Sua Magestade Sobre Se dar Capeláo para a Fortaleza de Santa Crús na Barra [f. 15-15v]

30) Lixboa 13 de Fevereiro de 1703 Ordem que Sua Magestade em Resposta da queixa que fes a Camera Sobre os escravoz em que manda informar ao Senhor Bispo [f. 15v-16]

31) Lixboa 4 de Mayo de 1703 Ordem em que Sua Magestade manda agradecer o Senhor Bispo o cuidado e zello da junta das Missoens pelo fim que se [dejara] [f. 16v]

32) Lixboa 4 de Mayo de 1703 Copia da carta que escreveo Sua Magestade ao Governador Sobre o lugar nas juntas [f. 16v-17]

33) Lixboa 8 de Fevereiro de 1704 Ordem em que Sua Magestade manda ao Senhor Bispo Sobre o Parocho de Aguasu e de Sáo Paulo [f. 17v]

34) Lixboa 14 de Marco de 1704 Ordem que Sua Magestade mandou Sobre a vesita da Misericordia [f. 17v-18]

35) Lixboa 27 de Janeiro de 1705 Ordem que Sua Magestade mandou Sobre os destrittoz deste Bispado e Acerbispado da Bahia [f. 18]

36) Lixboa 16 de Fevereiro de 1705 Ordem para Se mudar a Sé para a Igreja de São José [f. 18-18v]

37) Lixboa 21 de Fevereiro de 1704 Sobre Se Conceder aos moradores da vila de Pernaguá fazer hum Colegio de Padres da Companhia para Sua doutrina [f. 18v-19]

38) Lixboa 4 de Setembro de 1705 Ordem Sobre a Igreja da Crus da queixa do Mestre de campo [f. 19]

39) Lixboa 8 de Junho de 1706 Ordem Sobre a Igreja de Paratý [f. 19-19v]

40) Lixboa 21 de Junho de 1706 Ordem Sobre a Rezolução da Igreja da Se [f. 19v-21]

41) Carta que mandou o Senhor Bispo [f. 21-21v]

42) Lixboa 23 de Setembro de 1706 Ordem Sobre as duvidas do Juizo Eclesiastico apellar para a Coroa [f. 21v-22]

43) Lixboa 5 de Outubro de 1706 Ordem que Sua Magestade mandou para Se Retirarem os muitos Religiosoz que se achavão nas Minas [f. 22]

44) Lixboa a 12 de Outubro de 1706 Carta a favor do Padre Felipe Marques [f. 22-22v]

45) Lixboa 26 de Fevereiro de 1707 Ordem que Sua Magestade manda pagar oyto mil Cruzadoz para as obras da Igreja da Conceição [f. 22v]

46) Lixboa 26 de Fevereiro de 1707 Ordem que Sua Magestade mandou ao Governador para dar os oyto mil Cruzadoz para a obra das casas no Hospicio da Conceiçam [f. 22v-23]

47) Lixboa 29 de Março de 1707 Ordem Sobre Se fazerem os Sufragios pela morte del Rey [f. 23-23v]

48) Carta que Escreveo o Senhor Bispo a Sua Magestade Sobre o Colégio da vila de Pernaguá em 24 de Janeiro de 1708 [f. 23-24]

49) Lixboa 18 de Dezembro de 1710 Ordem que Sua Magestade mandou ao Ouvidor desta Capitania Sobre a mulher de Theodoro Mónz. e Se proceder Contra a dita [f. 24] 
50) Lixboa 20 de Março de 1707 Ordem em que Sua Magestade d não hirem os Negroz Minaz para as minaz e São Paulo Sem primeiro Se bautizarem e Cathequizarem. [f. 24v]

51) Lixboa 20 de Março de 1711 Asento que Se tomou no Consselho geral do Santo officio sobre a jurisdição que hão de Exercitar os ouvidores Geraez Ultramarinoz, assim a Respeito dos familiares Como sobre as materiaz do Fisco em virtude do Alvará de Sua Magestade que Seu Rejistro de 3 de Janeiro de 1711, e Sobre o que mais pertence a esta Materia [f. 24v-26]

52) Lixboa 9 de Junho de 1711 Ordem em que Sua Magestade estranha do Senhor Bispo o não Executtar as ordens que Se lhe tinháo mandado Sobre o não dar Licenssa a clerigos para irem as Minas e nem Se encarregarem a fradez os curatoz e isto Se lhe Recomenda outra vez [f. 26]

53) Lixboa 22 de Julho de 1711 Ordem que Sua Magestade mandou que todo o Clerigo ou frade que viesse de Portugal para o Rio de Janeiro Sem Licenssa que o Remetesse prezo para Portugal [f. 26v]

54) Lixboa 4 de Dezembro de 1711 Sobre o nascimento de huma Princeza de Portugal para se faserem as festas [f. 26v-27]

55) Lixboa 16 de Dezembro de 1711 Ordem em que se recomenda ao Senhor Bispo informe Sobre a queixa que os Paulistas fizerão do Padre Bento Curvelo Maciel e que não torne para a dita Igreja sendo certo a queixa e que busque Parocho que os Governe com Sussego [f. 27]

56) Conta que o Senhor Bispo Dom Frei Francisco de Sáo Jeronymo Sobre el Rey lhe estranhar Consentir que os Religiosoz fossem Parochoz nas Minas em 18 de Mayo de 1712 [f. 27v-28]

57) Lixboa 14 de Abril de 1712 Ordem em que Sua Magestade ordena ao Senhor Bispo mande notificar ao Prior Duarte Teixeira para hir para o Reino e quando duvida o faça embarcar [f. 28-28v]

58) Lixboa 29 de Abril de 1712 Ordem Sobre a queixa que Segunda ves fizerão os moradorez de São Paulo do Padre Bento Curvelo Maciel [f. 28v]

59) Lixboa 19 de Outubro de 1712 Ordem para o Senhor Bispo festejar o nascimento de hum Principe [f. 29]

60) Lixboa 7 de Novembro de 1712 Ordem em que Sua Magestade manda ao Senhor Bispo informar Sobre haver de Se fundar na vila de Pernaguá hum Colegio de Padres da companhia [f. 29-29v]

61) Lixboa 8 de Novembro de 1712 Ordem sobre se mandarem tres Religiosoz de Sáo Francisco que haviáo ficado para o Reyno [f. 29v]

62) Lixboa 9 de Novembro de 1712 Ordem em que Sua Magestade dá parte ao Senhor Bispo em que Se manda primeiro informar Sobre o Requerimento que o dito Prelado fés Sobre não se poderem Sustentar os Parochoz das Minas. [f. 30] 
63) Lixboa 15 de Novembro de 1712 Sobre a queixa que fizerão al Rey os moradores do ouro preto do Padre Claudio Grugel de Amaral Vigário da vara [f. 30-30v]

64) Lixboa 16 de Novembro de 1712 Sobre Se fundarem Hospicioz de Capuchoz de Santo Antônio no Ribeirão do Carmo vila Real e Rio das Mortes [f. 30v-31].

65) Lixboa 26 de Fevereiro de 1713 Sobre o Senhor Bispo fazer a diligência por hum frade de Sáo Francisco que tinha fogido da cadea de Pernambuco para o Remeter Se aparecesse nesta Cidade do Rio de Janeiro [f. 31]

66) Lixboa 26 de Janeiro de 1714 Carta em que Se manda Estranhar ao Senhor Bispo de não embarcar o Prior de chaves [f. 31v]

67) Lixboa 26 de Janeiro de 1714 Sobre a Igreja de Nossa Senhora da Conceição estar Sem Parocho e Só ter um clerigo [f. 31v-32]

68) Lixboa 11 de Fevereiro de 1714 Sobre a Igreja da Conceição e de Se dar todos os annos Sem mil réis para ao obra da Capela Mor [f. 32-32v]

69) Lixboa 2 de Março de 1714 Sobre a Igreja de Inhomerim estar Sem Parocho. [f. 32v]

70) Lixboa 11 de Abril de 1714 Ordem Sobre o Padre Claudio Gurgel do Amaral para Se Proceder Contra elle [f. 33]

71) Lixboa 30 de Abril de 1714 Ordem Sobre que o Senhor Bispo informe quantos Parochos Se achão nas Minas e os que São necessarios para as novaz Povoaçoens e a necessidade que há dellez. [f. 33-33v]

72) Lixboa 6 de Junho de 1714 Sobre Se festejar o nascimento de hum Infante.[f. 33v]

73) Lixboa 14 de Julho de 1714 Sobre Se fazerem outros hozpícioz No Ribeirão do Carmo Vila Real e Rio das Mortes, e Com a informação do Senhor Bispo Se havião a Se ter noz ditos Hospicioz Padres da Companhia [f. 34]

74) Lixboa 14 de Novembro de 1714 Sobre não Se embarcar logo o Prior de Chaves e extranhar ao Senhor Bispo o ter tanto tempo Sem observar as Suas ordens [f. 34v]

75) Lixboa 28 de Dezembro de 1714 Sobre não Serem obrigadas as propriedadez dos Ecclesiasticoz ao Resgaste e [corroído $15 \mathrm{~mm} \times 10 \mathrm{~mm}$ ] Serem [ilegivel] por Ministroz Secularez oz Seuz [bens] quando não Pagassem Logo com brevidade Contribuicão [f. 34v-35]

76) Lixboa 28 de Dezembro de 1714 Sobre os Requisitorias que alcanssarão as Mulheres de Seus Maridos que Se achavão nesta Cidade feitoz Soldados por não trazerem passaporte e por Se Remetterem para o Reyno. [f. 35]

77) Lixboa 6 de Janeiro de 1715 Para o Senhor Bispo passar a Corte para tratar da Saúde por molestias que Padesse pelo tempo que Se exprime no Breve de Sua Santidade [f. 35v-36]

78) Lixboa 25 de Janeiro de 1715 Ordem para o Senhor Bispo informar Sobre os Parochos que pedeão a Camera de Villa Rica para as duas freguezias [f. 36]

79) Lixboa 27 de Janeiro de 1714 Lixboa 27 de Janeiro de 1715 Ordem Sobre a queixa, que Se fizerão dos Religiozoz que andão nas Minas e Sua Magestade Recomenda ao Senhor Bispo para os fazer hir para oz Seus Conventos [f. 36-36v] 
80) Lixboa 28 de Janeiro de 1715 Para o Senhor Bispo hir para o Reyno tratar da Saude e voltar outra vez para o seu Bispado, ou Renunciar delle [f. 36v-37]

81) Lixboa 31 de Janeiro de 1715 Sobre o Padre Claudio Grugel do Amaral em que Sua Magestade Recomenda ao Senhor Bispo Se proceda Contra elle [f. 37]

82) Lixboa o $1^{\circ}$ de Fevereiro de 1715 Em que Se Recomenda muito ao Senhor Bispo tres Religiozoz de Sáo Francisco que andão pedindo esmollas para oz Santos Lugares para se lhe dar todo o favor e ajuda [f. 37v]

83) Lixboa 25 de Mayo de 1715 Sobre clerigo e frades que exercitão jurisdição Sem licenssa do Nuncio ou de Sua Magestade para os remeter para Lixboa [f. 37v-38]

84) Lixboa 11 de Novembro de 1715 Ordem que mandou Sua Magestade ao Governador Dom Brás estranhando lhe o não ter expulsado os Religiozoz que andavão pellas Minas com escândalo do Povo e occupandosse em Menisterioz [f. 38-38v]

85) Lixboa 14 de Novembro de 1715 Sobre o Senhor Bispo hir para o Reyno quando Se achasse melhor dos Seus achaques pela mesma Licenssa [f. 38v]

86) Lixboa 25 de Novembro de 1715 Sobre não fazer Parochoz aos Religiozoz e Só Sim a clerigos, e Se prover a Igreja de Goratingueta em hum [ilegivel] chamado Carlos de Figueiroa Monteiro [f. 39]

87) Lixboa 29 de Novembro de 1715 Sobre dar a Provedoria desta Capitania Sem mil réis por tempo de três annos para a Reedificacão da Igreja da Conceição e da Ilha Grande e oz Reys Magos visto não ter a provedoria da Vila de Santoz [f. 39v]

88) Lixboa 29 de Novembro de 1715 Sobre Se ter posto em Concursso a Matriz da Villa da Conceição por varias vezes e ninguem Se oppôz a dita Igreja. [f. 39v-40]

89) Lixboa 16 de Dezembro de 1715 Sobre Se Remeter hum Religiozo Carmelita descalsso de Santa Tereza que andava nas Minaz prezo E Se quer trarem [ilegivel] Seuz bem. [f. 40-41]

90) Lixboa 24 de Janeiro de 1716 Sobre os Parochos de Villa Rica [f. 41]

91) Lixboa 27 de Janeiro de 1716 Sobre hirem para as minas todos os annos Religiozoz de todas as Religioens desta Cidade e da Bahia pela falta de Parochos para missoens [f. 41-41v]

92) Lixboa 31 de Janeiro de 1716 Sobre oz officiaes da Camera da Villa de Nossa Senhora da Lár dos Pinhaez do Curitiba Sobre não terem quem lhes administrem oz Sacramentos [f. 41v-42]

93) Lixboa 3 de Fevereiro de 1716 Sobre Se pagarem as Congruas pontualmente que lhas não quis pagar o Governador por não lhe querer por o Cumprasse [f. 42-42v]

94) Lixboa 2 de Mayo de 1716 Sobre Se festejar mais o nascimento de hum Infante de Portugal [f. 42v]

95) Lixboa 10 de Mayo de 1716 Sobre que informe o Senhor Bispo dos clerigos ou Religiozos que Se achão nas terras da Sua jurisdição que exercitam jurisdição por ordem do Nuncio e Sem aprovacão de Sua Magestade [f. 43] 
96) Lixboa 28 de Mayo de 1716 Sobre não deffirir Sua Magestade a que se fundam hum Convento de Carmelitas descalçoz Como queriáo os moradores desta Cidade [f. 43-43v]

97) Lixboa 30 de Septembro de 1716 Sobre o Senhor Bispo nomear Parocho para a Nova Colonia estando Estabelecida pelos moradores [f. 43v]

98) Lixboa 26 de Janeiro de 1717 Sobre o Requerimento do Vigario da freguesia do Pillar de Aguasú Jagaré e Mirabahy em que Sua Magestade manda dar quatro mil cruzadoz para a obra da Capella Mor da Igreja [f. 44]

99) Lixboa 27 de Janeiro de 1717 Sobre o Senhor Bispo não querer uzar da Licenssa que Se Reconcedeo para hir para o Reino e de que tinha Cobrado melhoras Se deixava ficar de que Sua Magestade lhe mandou agradecer o zello [f. 44v]

100) Lixboa 29 de Janeiro de 1717 Sobre Se dar duzentos mil réis por anno por [?] taxa [?] de trez para a obra da Matris dos Reys Magos da Ilha grande, e Sua Magestade manda dar pela fasenda Real [f. 45]

101) Lixboa 29 de Janeiro de 1717 Sobre Sua Magestade mandar dar esmola para a Igreja de Santoz de duzentos mil réis cada anno pp.o de três annos [f. 45v]

102) Lixboa 8 de Fevereiro de 1717 Sobre o Recolhimento de freiras da Cidade de São Paulo; em que Se fundara Com ordem do Senhor Bispo Dom Jose de Barroz de Alarcão e que fugião mulherez de Seus maridoz para se Recolherem nelle em que Sua Magestade ordena ao Senhor Bispo o informe neste parecer [f. 45v-46]

103) Lixboa 8 de Fevereiro de 1717 Sobre o Vigario da Igreja Matris da cidade de São Paulo Bento Curvelo e queicha, que [corroído $20 \mathrm{~mm} \times 10 \mathrm{~mm}$ ] fazião do dito Vigario em que Sua Magestade Recomenda ao Senhor Bispo ponha tudo em boa paz e Soccego [f. 46-46v]

104) Lixboa 8 de Fevereiro de 1717 Sobre não impedir o Senhor Bispo aos clerigos das Minas que São Naturaes dellas a que venhão abaixo e para tornarem a ellas, e Só Sim aos clerigos de mar em fora [f. 46v-47]

105) Lixboa 11 de Fevereiro de 1717 Sobre huma excomunhão que Se botarão para se saber de huma joya que se furtou do Pescosso de huma Imagem de Nossa Senhora do Colegio desta cidade e se acham na meza de hum clérigo [f. 47-48v]

106) Lixboa 17 de Fevereiro de 1717 Sobre Requerimento que fizerão os officiaes da Camera da Villa de Nossa Senhora das Lus dos Pinhaes da Curutiba em que não tinhão os moradorez quem lhes administrar os Sacramentos e que morriao muitos sem ellez. [f. 48v-49]

107) Lixboa 2 de Março de 1717 Sobre o Requerimento da Madre Senhora Izabel de Santo Antonio para Se tirar humas Esmolas para se dotar huma freira Inglesinha [f. 49-49v]

108) Lixboa o $1^{\circ}$ de Abril de 1717 Sobre a ordem em que Sua Magestade mandou declarar ao Senhor Bispo a forma que Se devia Seguir para Senão faltar com o [pasto] Espiritual aos moradores das Minas em hir todos os annos em missão dous Religiosos das Religioens que aqui hão [f. 49v-50] 
109) Lixboa 12 de Abril de 1717 Em que as Religiosas descalças de Santa Thereza pedirão a Sua Magestade lhes mandasse tirar Suas esmolas nas Minas [f. 50-50v]

110) Lixboa 20 de Mayo de 1717 Sobre Sua Magestade pedir ao Senhor Bispo o número dos moradores que há no Seu Bispado tanto Brancos como escravos tanto da cidade como das outras Povoaçoens [f. 50v-51]

111) Lixboa a 2 de Septembro de 1717 Sobre que Sua Magestade Recomenda que Senáo ouver missionarios bastante, nesta cidade para as Minas os mande pedir a outro bispo da Bahia [f. 51]

112) Lixboa 31 de Janeiro de 1717 Sobre a queixa que fes Theresa Maria e acima do que Seu marido Filippe dos Santoz Freire para Se Remeter para o Registo [f. 51-51v]

113) Lixboa 5 de Julho de 1717 Sobre o nascimento de hum Infante para se festejar [f. 51]

114) Lixboa 6 de Novembro de 1717 Sobre uma queixa que fes do vigário da vara Sebastiam Ferreira de Sá que o dito vigário e seu Escrivão lhe furtara [huma] Sua mulata e a metera em caza. [f. 52-52v]

115) Lixboa 16 de Fevereiro de 1718 Sobre a taxa certa que Se por aos Parochos das Minas e que hão de levar de conhecenssa e náo pelo excessivo presso que elles poem a Seu arbítrio [f. 52v-53]

116) Lixboa 16 de Fevereiro de 1718 Ordem que Sua Magestade mandou ao Governador de São Paulo sobre as conhecencias dos vigarios e Se publicou nas Minas [f. 53-54]

117) Lixboa 23 de Agosto de 1718 Sobre o Parocho de São Paulo Bento Curvello Maciel sobre as queixas que Se fizerão delle [f. 54-54v]

118) Lixboa 23 de Agosto de 1718 Recomendação que fes Sua Magestade ao Senhor Bispo para que náo consinta que os escravos que vem de Angola e da Costa da Mina vão para as Minas Sem Se bautizarem e que asim ficão na cidade mesmo tempo Sem Serem Bautizadoz [f. 54v-55]

119) Lixboa 26 de Agosto de 1718 Sobre em que Sua Magestade Recomenda ao Vigario o Doutor Pedro Frei [?] da Inoja Valasco que o Senhor Bispo o consserve na mesma Igreja pelo Seu bom procedimento [f. 55]

120) Lixboa 5 de Dezembro de 1718 Sobre o Requerimento que fes a Sua Magestade Padre João Reverendo [ilegivel] de Angola em que os negros de Angola, Costa da Mina e Congo asim que chegavam logo os faziam Remeter para as minas sem se bautizarem e nem serem cathequizadoz [f. 55-56]

121) Lixboa 26 de Dezembro de 1718 Em que Sua Magestade Recomenda ao Senhor Bispo que a parte aquellaz mulherez que vivem deshonestamente que estão no Recolhimento ou Convento da Cidade de Sáo Paulo e se conserve em mesma não Ser o dito Convento [f. 56-56v]

122) Lixboa 20 de Janeiro de 1719 Sobre em que Sua Magestade Recomenda ao Senhor Bispo Segunda ves lhe mande huma Lista dos moradorez brancoz e escravoz homens e mulherez de toda a Cidade e villas pelos Roez das fortificaçoes de cada freguesia [f. 56v-57] 
123) Lixboa 24 de Janeiro de 1719 Sobre as contendaz que teve o vigario da vara com o Ouvidor da Comarca do Reverendo das Mortes sobre a prizão de hum clerigo que furtara huma joya de Nossa Senhora da Igreja dos Padres da Companhia desta Cidade [f. 57-57v]

124) Lixboa 27 de Janeiro de 1719 Sobre Se darem ao Parocho das minas a Sua Congrua certa de 200 réis por taixação certa que Se pos; para não levarem conhecenças exorbitantes [f. 57v]

125) Lixboa 8 de Fevereiro de 1719 Sobre o excesso que fes hum clerigo em São Paulo em tirar hum negro que hia para as Gales da prizão [f. 58]

126) Petição que Se fes em Lixboa a Sua Magestade o requerimento do Senhor Bispo por seu procurador Sobre a mudança da Sé para outra parte [f. 58-58v]

127) Lixboa 16 de Fevereiro de 1719 Carta que de Lixboa escreveo o procurador do Senhor Bispo aserca do Requerimento da Igreja da Candelaria para Ser Sé [f. 58v-60]

128) Lixboa 15 de Março de 1719 Sobre o Requerimento da Prioreza do Convento de Santo Alberto da Cidade de Lixboa freiras, carmelitas descalcas pedirem Licenssa a Sua Magestade para mandarem tirar Suas esmolas no Rio de Janeiro e Seus destritos [f. 60v]

129) Lixboa 27 de Abril de 1719 Sobre os escravos que vem de Angola e dos mui portoz que Se desembarcáo e váo para as Minas Sem Serem Bautizados e os que vem doentes que Se acuda Logo com o Sacramento do Bautismo [F. 60v-61v]

130) Lixboa 30 de Outubro de 1719 Sobre as esmolas que tirou o Senhor Bispo para a religioza do Convento de Ilha Vissoza para uma ingllezinha tomar o habito em que Se tinha tirado 2.248 folhas e Remetidas para o Consselho Ultramarino [f. 61v-62]

131) Lixboa 28 de Novembro de 1719 Sobre que informe o Senhor Bispo a Sua Magestade do pedido dos oficiaes da Camera da vara de Jundiahy quererem Parocho confirmado. [f. 62]

132) Lixboa 10 de Janeiro de 1720 Sobre a queixa que fizerão os officiaes da Camera a Sua Magestade do vigário da vara não querer dar Licenssa para em dia de Sáo João Saer por Sacramento na freguesia de São João Del Rey e o do que mais procedeo [f. 62-62v]

133) Copia da Reprezentação que fizeráo os terceiroz de Nossa Senhora do Monte do Carmo da vara de Surucaba para Sua Magestade lhe conceder Licenssa para Se fazer hum Hospicio em que asistáo nelle religiozoz para Se fazer o culto Divino e observancia da dita ordem terceira [f. 63]

134) Copia da Reprezentação que fizerão a Sua Magestade os officiaes da Camera da Vara da Sorocaba para lhe conceder Licenssa de Se fazer hum Hospicio de Nossa Senhora do Carmo e ordem terceira e ter nelles Religiaoz para Se fazer o Culto divino [f. 63-63v]

135) Copia da Reprezentação que fizerão a Sua Magestade os officiaes da camera da Vara de Itú pedindo Licenssa para Se fazer um Hospicio para Religiozoz de Nossa Senhora do Carmo e Servir de ordem terceira [f. 63v-64]

136) Copia da queixa que fizerão a Sua Magestade os officiaes da Camera da vara de São João del Rey do vigário da vara da desattenção que lhe fizera na Caza na Camera [f. 64] 
137) Copia da Reprezentação que fes a Sua Magestade o Juis ordinario da vara de Sáo João del Rey Sobre o Vigário da vara da dita Manuel Cabral Camello [f. 64v]

138) Lixboa 16 de Agosto de 1720 Ordem em que Sua Magestade Recomenda ao Senhor Bispo que oz Parochoz das Igrejas das Minas Sejāo Colladoz [f. 64v-65]

139) Lixboa 6 de Septembro de 1720 Sobre haverem dois Bispos hum em São Paulo e outro nas Minas por Se atalharem mais os prejuizos [f. 65]

140) Lixboa 5 de Dezembro de 1720 Sobre que Sua Magestade ordena ao Senhor Bispo informe Se hé conveniente fundarsse hum Hospicio de Nossa Senhora do Carmo na vila de Sorocaba de Nossa Senhora da Candelaria e Seus moradorez correm com a despeza [f. 65v]

141) Lixboa 12 de Dezembro de 1720 Sobre o Requerimento que fizerão os moradores de Campo grande para Se fazer freguezia da Capella de Nossa Senhora do Desterro em que Sua Magestade manda ao Senhor Bispo que informe Com Seu parecer e o procurador mor da fazenda do Lugar e cítio e da despeza que fará [f. 65v-66]

142) Lixboa 5 de Dezembro de $1720^{25}$

143) Lixboa 19 de Dezembro de 1720 Sobre a queixa que fes a Camera da Vila de Sáo João del Rey do vigário da vara Padre Manoel Cabral Camello [f. 66v]

144) Lixboa 4 de Janeiro de 1721 Sobre o vigario da vila de Nossa Senhora do Carmo o Padre Doutor Pedro Frz.de Inojosa em que Sua Magestade o Recomenda ao Senhor Bispo o provar em huma das melhores Igrejas das minas tendo bom procedimento [f. 66v-67]

145) Lixboa 2 de Fevereiro de 1721 Carta escrita ao Senhor Bispo em que Se Recomenda para Se tirarem pelos Frades da Caza Santa esmolas para a mesma em que Se Recomenda ao Senhor Bispo dê toda ajuda e favor [f. 67-67v]

146) Lixboa 18 de Março de 1721 Em que Sua Magestade Recomenda ao Senhor Bispo para que mande tirar humaz esmollaz para o dote de uma freyra Dona Anna de [ilegivel] Payva [f. 67v]

147) Lixboa 31 de Março de 1721 Sobre a Igreja da Sé de Se mudar para a Igreja da Crus e das esmollas que Se tirarão para ajuda da obra [f. 68]

148) Lixboa 2 de Abril de 1721 Sobre a mudanssa da Sé para a Candelaria e não para a Igreja da Crus em que Sua Magestade ordena Se dê vinte mil cruzadoz para a dita obra [f. 68v]

149) Certidáo do Presidente do clero da Santa Caza da Mizericordia da cidade de Lixboa em que ensinua o modo ou estilo que Se observa no hospital com os que Se Sepultão e das vizitas que Se fazem e dos Irmaoz da dita [f. 68v-69v]

150) Lixboa 27 de Mayo de 1722 Sobre não haverem mazcaradoz pela festa daz virgénz pelas desordens que há e inquietaçoens [f. 69v]

151) Lixboa 9 de Junho de 1722 Sobre dous Religiozos Missionários Capuchos em que aribarão a esta Cidade em que Sua Magestade Recomenda os fação hir para a Sua missão para São Thomé pela Bahia [f. 70]

\footnotetext{
${ }^{25}$ Não há título, é sequência do documento da página anterior.
} 
152) Lixboa 7 de julho de 1722 Sobre oz Irmaos da Mizericordia das duvidaz que tinhão como Parochos das frequesia ao enterrar doz defuntoz e ha vezita da dita Caza e dos mais que Se observa [f. 70-70v]

153) Lixboa 10 de Mayo de 1723 Sobre que Sua Magestade Recomenda ao Cabbido para não passar dimisoriaz a pessoa alguma por não Serem dignas de Serem Sacerdotez [f. 71]

154) Lixboa 17 de Mayo de 1723 Sobre os frades e clerigos que andao espalhados pellaz Minaz em que Sua Magestade Recomenda que os façao Sahir dellas e que So fiquem aquelles clérigos que forem [ilegivel] [f. 71-71v]

155) Lixboa 19 de Mayo de 1723 Sobre o Requerimento que fes a Camera ao Bispo Dom Francisco e o Marques de Angeja para Se fundar hum Convento de carmelitas descalçaz a que Sua Magestade náo quer defirir [f. 71v-72]

156) Lixboa 22 de Mayo de 1723 Sobre a Contenda que teve o Vigário da vila de Santoz Com o Juis de fora e mais officiaez da Camera Sobre os asentos que havião de ter nas Igrejas em dia da festa de Sáo Sebastiam [f. 72-72v]

157) Lixboa 25 de Janeiro de 1724 Sobre quererem os officiaes da Camera calsar as Ruas por Razão das agoas que Se empossavao nellas e prejudicavao a Saude dos moradorez e Cazas [f. 72v-73]

158) Lixboa 14 de Junho de 1724 Sobre o Requerimento a Sua Magestade dos officiaes da Camera da Cidade de Cabo frio para fazersse huma Igreja nova para Se colocar huma Imagem de Nossa Senhora da Conceição que Se achou na praya entre hunz penedoz. [f. 73-73v]

159) Copia da carta que Escreverão a Sua Magestade os officiaes da Camera da villa de Paraty para que a Igreja Matris de Nossa Senhora dos Remedioz fosse collada pelas faltas que haviáo [f. 73v-74]

160) Copia da petição que fizerão a Sua Magestade os moradorez da vila de Paraty Sobre terem Vigario Collado na dita freguezia [f. 74-74v]

161) Lixboa 15 de Novembro de 1724 Sobre em que Sua Magestade Recomenda ao Deão Gaspar Gonsalvez de [ilegivel] para Remeter as esmolas que Se tirarão nas minas para o dote da Inglesinha do Convento de Villa visosa [f. 74v-75]

162) Lixboa 6 de Março de 1725 Ordem em que Sua Magestade ordena ao Cabbido informe Sobre o Requerimento dos officiaes da Camera e moradorez da Vila de Paraty Sobre terem vigário collado na dita freguesia [f. 75-75v]

163) Lixboa 24 de Março de 1725 Ordem Sobre as pessoas que Se quizessem opor a conezias e beneficios do Bispado Ecclesiastico haviao de aprezentar Dimisurias e folha Corrida Com mais papeis pertencentes com informação do Cabbido [f. 75v]

164) Lixboa 23 de Abril de 1725 Sobre Se mandar Vigario Geral para a Cidade de São Paulo em que Sua Magestade ordena ao Cabbido eleja um dos Vigarios da Vara de mais Suficiencia [f. 76] 
165) Lixboa 28 de Abril de 1725 Provizão em que Sua Magestade Concede ao Senhor Bispo para o Seu Meirinho Geral poder andar Com vara branca [f. 76-76v]

166) Lixboa 28 de Abril de 1725 Provizão para que as pessoas que forem Sentenciadaz pela Jurisdição Eccleziastica e clerigos Sejão prezas na cadea publica por não haver aljubi do Eccleziastico [f. 77-77v]

167) Lixboa 2 de Mayo de 1725 Ordem em que Sua Magestade Recomenda ao cabbido não deyche hir as minas os Religiozoz Capuchoz, e que Se Se achar Lá algum os fação Logo vir para o Seu Convento [f. 77v-78]

168) Lixboa 13 de Mayo de 1725 Ordem que Sua Magestade manda dar ao Senhor Bispo 120000 réis todos os annoz para appozentadoria das Cazas em que vive [f. 78-78v]

169) Lixboa 19 de Mayo de 1725 Sobre que no Colegio da Companhia haja mais tres claces do Estudo de filozofia Theologia e moral e das pessoas que se houverem de ordenar mostrarem certidão de dous annoz della de Seus Mestrez [f. 78v-79]

170) Lixboa 19 de Mayo de 1725 Sobre os Religiozos Capuchoz desta Cidade Se levantarem com os Seuz Superiorez em que Sua Magestade Recomenda a pas delles [f. 79-79v]

171) Resposta da Carta acima que mandou o Senhor Bispo a Sua Magestade da Provizáo que veyo Sobre a pás dos Capuchoz [f. 79v-80v]

172) Lixboa $1^{\circ}$ de Junho de 1725 Alvará em que Concede Sua Magestade ao Senhor Bispo para poder nomer [sic] Conesias e meyas Conesias beneficios Igrejas no Seu Bispado depois da Sua Residencia Excepto a dignidade de Deam que hé Reservada ao dito Senhor [f. $80 \mathrm{v}-81 \mathrm{v}$ ]

173) Lixboa 6 de Junho de 1725 Em que Recomenda Sua Magestade ao Senhor Bispo as esmollas para o dote da Inglezinha do Convento de villa Vissoza. [f. 81v-82]

174) Resposta da carta acima e ordem de Sua Magestade escrita pelo Senhor Bispo a Respeito das esmollas para a Inglesinha [f. 82]

175) Lixboa 14 de Junho de 1725 Sobre o requerimento que fizerão a Sua Magestade os officiais da Camera da Cidade de Cabo Frio para Se fazer huma Igreja nova e pedião huma ajuda de Custo [f. 82v]

176) Resposta da Ordem em [fronte] de 14 de Junho que escreveo o Senhor Bispo informando sobre o Requerimento da Cidade de Cabo Frio [f. 83]

177) Lixboa 20 de Junho de 1725 Em que Sua Magestade Recomenda ao Senhor Bispo de tomar Conhecimento de humaz esmollas que derão os freguezes da freguezia da Capitania do Espirito Santo para Se fazer nova Matriz e entregarão ao vigario [f. 83-83v]

178) Resposta da ordem acima do Requerimento do Capitam mor da Capitania do Espirito Santo das esmollas que Se tirarão para Se fazer a Igreja nova. [f. 83v-84]

179) Lixboa 20 de Junho de 1725 Sobre o [queixara] do Padre Vigario João Francisco de Lira do Povo da Capitania de Espirito Santo de não dar expedição as partes e Reter as Cauzas [muitos] annoz [f. 84] 
180) Reposta da ordem acima das queixas do Senhor Vigario da Vara da Vitória João Francoso de Lira [f. 84-84v]

181) Lixboa 11 de Junho de 1725 Sobre Arquivoz que fizerão a Sua Magestade a Camera da Vila do Principe do Serro do frio do Padre Antonio da Silva Bravo vizitador que foy a ella [f. 84v]

182) Lixboa 22 de Junho de 1725 Sobre as contendas que houve entre os Juis ordinario da Vila do Carmo com o Vigario da Vara aserca de dous clérigos que tinhão suas tavernaz e Se [prohibirao] [f. 85]

183) Lixboa 6 de Julho de 1725 Sobre que o Cabbido Sé de vacante mandara Retirar os clerigos que estavão em Vila Real nas minaz de que a Camera se queixara a Sua Magestade [f. 85-85v]

184) Lixboa 19 de Julho de 1725 Sobre Sua Magestade ordenar ao Senhor Bispo para castigar o Padre José Nogueira Ferraz vigario da Igreja de São José por soltar todos os prezos da cadea que estaváo para hir para o Monte [Vidio] [f. 85v-86]

185) Resposta da carta e ordem acima da queixa do Vigário o Padre José Nogueira Ferraz Vigário da Igreja de Sáo Jose [f. 86-86v]

186) Lixboa 4 de Septembro de 1725 Em que Sua Magestade recomenda ao Senhor Bispo Se proceda Contra o Conego João Dias Ferreyra sobre a devassa que delle Se tirou nas Minas sendo Vigário [f. 86v-87]

187) Reposta da ordem acima que deu o Senhor Bispo da devassa do Conego João Dias Ferreira [f. 87]

188) Lixboa 10 de Septembro de 1725 Sobre a queixa do Povo das Minas a Sua Magestade dos Vezitadorez de levarem exorbitancias no tempo da vesita na condemnação e tributo que poem os ditos Vizitadores [f. 87-87v]

189) Resposta da carta acordem [sic] acima das condenaçoens da vizita [f. 87v-88]

190) Lixboa 10 de Septembro de 1725 Sobre a queixa que fes acima da Vila do Carmo dos Parochos quererem levar Conheccenças Exorbitantez [f. 88-88v]

191) Resposta a Sua Magestade da ordem acima das benezes e conhecensias que devião Levar os Parochoz [f. 88v-89]

192) Lixboa 11 de Septembro de 1725 Sobre Se fazer do Recolhimento da Cidade de São Paulo se fazer Convento de Freiras professaz em que Sua Magestade manda informe o Senhor Bispo Com Seu parecer. [f. 89v-90]

193) Resposta da ordem acima aserca do Convento de Freiras da Cidade de São Paulo [f. 90]

194) Lixboa 14 de Septembro de 1725 Em que Sua Magestade Recomenda ao Senhor Bispo mande tirar humas esmollaz pelas Minaz para dote de huma Inglesa Religioza do Convento de São Bento [f. 90-90v]

195) Lixboa 19 de Septembro de 1725 Sobre a Representação que fes a Sua Magestade a Camera da Vila do Rio de São Francisco sobre a falta que padessem de Parocho que lhes administrem os Sacramentoz [f. 90v-91] 
196) Resposta da ordem acima do Requerimento da Camera da Vila de Sáo Francisco Xavier sobre pedirem Parocho Pago por Sua Magestade [f. 91]

197) Lixboa 21 de Septembro de 1725 Sobre Levarem as Merces das Capellas das Minas pela Licenssa que dao de Se cantar huma exorbitancia, e na mesma forma os Vigários das varaz em dar Licenssa para Se copor [sic] o titulo em alguma festa [f. 91v]

198) Resposta da ordem acima aserca das Merces das Muzicaz das Minaz e vigario da vara [f. 91-92]

199) Lixboa 26 de Septembro de 1725 Sobre as contendaz que tiverão os vigarioz da vara e da Igreja da villa de Santoz: Com os Irmaoz da Mizericordia [f. 92]

200) Resposta da ordem acima aserca doz Vigários da Prasa de Santoz Com os Irmaoz da Misericordia [f. 92-92v]

201) Lixboa 14 de Outubro de 1725 Sobre o Conego João [Dias] Ferreira do procedimento da Sua devassa <esta ordem de 14 de outubro pertensse ao anno de 1726 que por erro Se Lanssou no anno de 17 [corroído $5 \mathrm{~mm} \times 10 \mathrm{~mm}$ ] com as outras de [corroído $3 \mathrm{~mm} \times 10 \mathrm{~mm}$ ] = e táo bem a [corroído $5 \mathrm{~mm} \times 10 \mathrm{~mm}]>$ [f. 92v-93]

202) Lixboa 20 de Outubro de 1725 Sobre o Conego João Dias Ferreyra Vigario da Villa de Nossa Senhora do Carmo em andar Sempre com os Seuz freguezes em Contendaz [f. 93-94]

203) Resposta da ordem acima aserca do Conego Joáo Diaz Ferreira quando foy Parocho e vizitador nas Minas [f. 94-94v]

204) Lixboa 12 de Novembro de 1725 Sobre em que Sua Magestade Recomenda ao Senhor Bispo a esmolla da Inglezinha do Convento de Villa Vissoza [f. 94v-95]

205) Lixboa 5 de Fevereiro de 1726 Carta que Se escreveo ao Senhor Bispo de que na Cidade haviáo Varioz Religiozoz que Recebaão muitas fasendas furtadaz [f. 95-95v]

206) Reprezentação que fizerão os oficiaes da Camera da villa de Paraty queixandosse contra o Padre Manoel Bras Cordeiro Vigario da mesma Igreja de Paraty. [f. 95v-96]

207) Lixboa 9 de Agosto de 1726 Sobre Se tirarem humaz esmollaz para as freiras do Convento de Nossa Senhora da Conceição dos Cardaez e carmelitas descalçaz [f. 96-96v]

208) Lixboa a 2 de Setembro de 1726 Sobre que Sua Magestade ordena ao Senhor Bispo ponha a Igreja de Nossa Senhora da Lus dos Pinharez da Curitiba em Concursso [f. 96v]

209) Lixboa 9 de Outubro de 1726 Sobre o Mestre das Musicaz das Minas e vigario das [corroído $15 \mathrm{~mm} \times 10 \mathrm{~mm}$ ] Sobre Levarem exorbitancias [corroído $5 \mathrm{~mm} \times 10 \mathrm{~mm}$ ] Licençaz que davão [f. 97]

210) Lixboa 9 de Outubro de 1726 Sobre os emolumentos e Salarioz [ilegivel] [ilegivel] [ilegivel] que Se levão no juizo Ecclesiastico dos Vigarioz da vara das Minaz. [f. 97-97v]

211) Lixboa 9 de Outubro de 1726 Ordem em que Recomenda Sua Magestade ao Senhor Bispo o Castigar ao Padre Jose Nogueira Ferraz por Soltar os prezoz da Cadea da vila se São Joze Sendo Vigário [f. 97v] 
212) Lixboa 10 de Outubro de 1726 Sobre Se tirarem humas esmollaz nas Minas para o Convento das Religiozaz e freyras de Santo Alberto da Cidade de Lixboa [f. 98]

213) Lixboa 14 de Outubro de 1726 Sobre as queixas do Padre João Francozo de Lira Vigario da Igreja da Vitoria da Vila da Cappitania do Espírito Santo para o Senhor Bispo dar a providencia para Se evitarem [f. 98-98v]

214) Lixboa 26 de Outubro de 1726 Em que Sua Magestade Recomenda ao Senhor Bispo as esmollas para a Inglesinha do Convento de Nossa Senhora da Conceição de Villa Vissoza [f. 98v-99]

215) Lixboa 6 de novembro de 1726 Em que Sua Magestade Recomenda ao Senhor Bispo que na vezita das Minaz mande fazer huma Lista do número, das pessoaz que há em cada freguesia Brancoz e pretoz homens e mulheres Casadoz e Solteiros e Crianças que não Recebem o Sacramento [f. 99]

216) Lixboa 15 de Novembro de 1726 Sobre que Sua Magestade ordena ao Senhor Bispo declare o meyo para Se aquietarem as desordenz e perturbaçoenz dos Religiozoz Capuchoz de Nossa Senhora da Conceição desta Cidade [f. 99v]

217) Lixboa 18 de Novembro de 1726 Sobre os Visitadorez principalmente os de Pernagua náo Se entrometerem a tomar Conta das Confradias Leigas por Ser da jurisdiçao Secular olhar [f. 99v-100]

218) Lixboa 19 de Novembro de 1726 Sobre o Requerimento que fizerão os officiaez da Camera de Sáo Paulo a Sua Magestade para Se fazer hum Convento de Freyras professaz. [f. 100]

219) Lixboa 22 de Novembro de 1726 Sobre huns clerigos e hum Religiozo de Jérusalem que vierao para esta Cidade Sem licenssa da Sua Magestasde e o Governador os mandou prender para hirem para Lixboa [f. 100-100v]

220) Lixboa 10 de Dezembro de 1726 Sobre Se fazer hum convento na Vila de Itú da Cidade de São Paulo de Religiozoz de Nossa Senhora do Carmo [f. 100v-101]

221) Patrimonio dos Religiozoz de Nossa Senhora do Carmo da Villa de Itú de dos Religiozoz para cima [f. 101-101v]

222) Lixboa 10 de Dezembro de 1726 Sobre Se taixar o estependio certo das conhecenssaz e Salarioz dos vigarioz das varas e das Igrejas das Minaz <Ver folha 11, Ver folha 119 verso> [f. 101v]

223) Lixboa 17 de Septembro de 1726 Sobre haver Parocho na Igreja da Povoação de São Matheuz [f. 102]

224) Lixboa 19 de Dezembro de 1726 Sobre se acomodarem douz Religiozos Capuchoz Italianoz que o cabbido deixou [ilegivel] para fazerem Missoenz [f. 102-102v]

225) Lixboa 13 de Mayo de 1725 Ordem em que Sua Magestade manda dar ao Senhor Bispo de sua Congrua hum Conto de Reiz para elle e pagamentos dos Seuz officiaez e para esmollaz cada anno e foy Remitida ao Vice Rey da Bahia < esta ordem pertence ao anno de 1725 que por descuido Se Lançou no anno de 1727> [f. 102v-103] 
226) Copia de huma Ordem que Sua Magestade mandou ao Senhor Bispo Sobre o Requerimento do Provedor dar Fasenda Real das Minaz Antonio Berco delRio para Se fazer em Vila Rica huma Igreja que possa servir de Cathedral [f. 103v]

227) Resposta da Ordem acima que mandou o Senhor Bispo da Igreja em villa Rica [f. $103 \mathrm{v}-104]$

228) Petição que fes o Senhor Bispo ao Vice Rey da Bahia para lhe mandar pagar a Congrua de hum conto de réis pela Provizão que veyo de Sua Magestade [f. 104]

229) Lixboa 28 de Janeiro de 1727 Sobre se por a Igreja Matris do Bom Jhesus da vila do Iguape em Concursso por estar vaga por falecimentó do Vigario Collado e Remetersse os Examez dos oppositorez a Mesa da Consciencia [f. 104v-105]

230) Lixboa 2 de Fevereyro de 1727 Sobre as queixaz que fes a Camera da villa de Paraty a Sua Magestade do Padre Vigario Manoel Bráz Cordeiro Pedindo outro Parocho [f. 105]

231) Lixboa 4 de Fevereiro de 1727 Em que pedio o Governador da Cidade de Sáo Paulo a Sua Magestade Vigario geral para a dita para Exercer em falta de Bispo por evitar muitas Ruinaz dos clérigos [f. 105-105v]

232) Lixboa 4 de Fevereiro de 1727 Sobre Se tirarem humaz Esmollaz para Se fazer humaz obraz no Convento das Religiozaz de Nossa Senhora da Piedade da Esperanssa da Cidade de Lixboa [f. 105v-106]

233) Lixboa 14 de Marco de 1727 Sobre Se fazer huma Igreja em Villa Rica para Ser Cathedral, e que informe o Senhor Bispo Com Seu parecer [f. 106-106v]

234) Resposta da Ordem acima aserca de Se fazer Igreja em Vila Rica para Ser Cathedral [f. 106v]

235) Lixboa 14 de Março de 1727 Sobre as Contendaz dos Religiozos Capuchoz dessa Cidade e Se Suspender o dereito da Sagrada Congregaçáo [f. 106v-107]

236) Lixboa 15 de Março de 1727 Carta que mandou o Secretário ao Senhor Bispo Sobre deixar pedirem esmollaz huns Religiozoz para Terra Santa [f. 107]

237) Lixboa 16 de Março de 1727 Ordem ao Senhor Bispo para fazer observar o privilegio que tem os Religiozos do Convento da Santissima Trindade para terem pedidores para esmollaz para o Seo Convento [f. 107v]

238) Lixboa 21 de Março de 1727 Copia da Carta e ordem que mandou Sua Magestade ao Provincial do Convento de Nossa Senhora da Conceyçáo dos Capuchos desta cidade Sobre fazer hum Hospicio Sem Sua Licenssa [f. 107v-108]

239) Lixboa 23 de Março de 1727 Carta do Secretario ao Senhor Bispo em que lhe aviza da Carta que foy ao Provincial dos Capuchoz aserca do hospicio que se fés Sem sua Licenssa [f. 108]

240) Lixboa 23 de Mayo de 1727 Sobre Se tirarem humas esmollaz pellas Minas para as Religiosaz do Convento de Corpus Christi de São Domingos de Vila Nova de Gaya do Porto [f. 108v] 
241) Mandado que o Vice Rey da Cidade da Bahia mandou para Se pagar ao Senhor Bispo hum Conto de Reiz Cada ano do Contrato das Baleas de Sua Congrua [f. 108v-109]

242) Lixboa 15 de Janeiro de 1728 Sobre Se festejarem os Cazamentoz dos Principes de Portugal com os de Castella [f. 109-109v]

243) Lixboa 17 de Janeiro de 1728 Sobre as esmollaz para a Inglesinhaz que está no Convento da Conceição de Villa Vissoza [f. 109v-110]

244) Lixboa 27 de Janeiro de 1728 Sobre haver Parocho da Igreja de Nossa Senhora do Desterro da Ilha de Santa Catherina para administrar os Sacramentoz aquelloz moradores [f. 110-110v]

245) Lixboa 29 de Janeiro de 1728 Sobre o Requerimento que fizerão a Sua Magestade as Recolhidas do Recolhimento das Mocaúbaz do Rio das velhas, para se lhe confirmarem humas terraz que lhes forão dadas [f. 110v]

246) Lixboa 24 de Marco de 1728 Sobre que Sua Magestade Recomenda ao Senhor Bispo para que acomode ao Padre Frei Agostinho na Igreja da Ilha de Santa Catherina por Ser Conveniente [f. 110v-111]

247) Lixboa 8 de Julho de 1728 Sobre Se tirarem humas Esmollas para as Recolhidas do Recolhimento de Nossa Senhora da Natividade Caza Pia das Convertidas [f. 111-111v]

248) Resposta de huma ordem que veyo ao Senhor Bispo Sobre as contendaz Com os Irmãos da Mizericordia desta Cidade <Esta resposta pertence ao ano de 1729 que Se Segue adiante que por descuido se lanssou aqui> [f. 111v-112]

249) Lixboa 26 de Outubro de 1728 Sobre a queixa que fizerão a Sua Magestade os Irmãos da Misericordia do Provizor e do Senhor Bispo [f. 112-112v]

250) Lixboa 26 de Novembro de 1728 Sobre os Parochos fazerem aSento nos Livros das Parochia dos defuntos e dos Seus ttestamentoz Com toda a Clareza para Se Saber os que morrem abintestado < ver folha $125 / /$ e folha $135>$ [f. 112v-113]

251) Lixboa 11 de Dezembro de 1728 Sobre que Sua Magestade agradesse o dinheiro que Remeteo o Senhor Bispo das esmollaz para o dote da Inglesinha [f. 113-113v]

252) Lixboa 21 de Janeiro de 1729 Sobre as contendaz dos Menistroz Secularez Com os Vigarioz das varas das Comarcaz em Se Rever as cauzaz [f. 113v]

253) Lixboa 26 de Janeiro de 1729 Sobre os Parochoz e Ecclesiasticoz das Minas Levão por tomar contas das Igrejas tres oytavaz de ouro [f. 113v-114]

254) Lixboa 26 de Janeiro de 1729 Sobre o Vigario da Vara da Cidade da Cidade [sic] de São Paulo Com o Carcereyro por deixar fugir hum clerigo e prender o dito em huma Corrente em sua Caza [f. 114-114v]

255) Lixboa 31 de Janeiro de 1729 Sobre o Meirinho do Campo da Cidade de Sáo Paulo tirar hum preco que Se tinha metido na Igreja e Se abraçara com huma Imagem de Santo Christo e o dito Meyrinho o tirava e quebrara a Imagem. [f. 114v-115]

256) Lixboa 21 de Fevereiro de 1729 Sobre a queixa que fes a Sua Magestade o Thezoureiro dos Auzentez da comarca do ouro preto do Vigario da vara por morte de hum clerigo 
Sem testamento e querer o Vigario tirar huma negra, que era de letuoza [sic] para o Senhor Bispo [f. 115-115v]

257) Copia de huma petição que mandou o Vigário da Candelaria para que Sua Magestade nomeasse ou fizesse hum fabriqueiro e Segundo Coadjutor para dita Igreja para guardar os benz da dita fabrica da Igreja [f. 115v]

258) Lixboa o $1^{\circ}$ de Abril de 1729 Sobre que Sua Magestade manda ao Senhor Bispo informe sobre a petição do Vigário da Candelaria e que remeta a informação [f. 115v-116]

259) Lixboa 12 de Abril de 1729 Em que Sua Magestade encomenda ao Senhor Bispo para se tirarem humas esmollaz para huma Ermida dos Religiozoz Alemães de São João Nipomoceno [f. 116-116v]

260) Lixboa 21 de Mayo de 1729 Sobre Se por em Concursso a Igreja de Santa Anna da Villa de Nossa Senhora da Conceiçao de Itanhaem pela desistencia e deixaçáo que della fes o Padre Manoel Gonçalves Soutto. [f. 116v-117]

261) Lixboa 22 de Mayo de 1729 Sobre Se tirarem humas Esmollaz para as obraz do Convento das Religiozaz Agostinhas descalssas nas Minaz [f. 117-117v]

262) Lixboa 22 de Septembro de 1729 Sobre os Exorbitantez selarioz que se levão no juizo Ecclesiástico por tomarem Conta as Comfrarias [f. 117v]

263) Informação que deu o Senhor Bispo a Sua Magetade Sobre as Conhecenssaz e petição que fizerão o Vigário da Candelaria Cura da Se em Julho de 1729 < ver folha 119 e folha $101>$ [f. 117v-118]

264) Lixboa 26 de Janeiro de 1730 Sobre o Vigario da Matris de Mogi Gervasio de Abrunhoza Se entrometer na Junta que fés o Sennado da Camera Sobre Se ajustar o donativo que Se quis oppor as promessaz da quantia que Se haviáo de offerecer. [f. 118-119]

265) Lixboa 4 de Fevereiro de 1730 Ordem que mandou Sua Magestade ao Provedor dos defuntoz E auzentes Sobre a duvida que teve na provizão para que Servisse o Provedor da Repartição em Sua ausência [f. 119-119v]

266) Lixboa 4 de Março de 1730 Sobre o Requerimento que fes a Camera da Vila de Itu a Sua Magestade de que querem os Parochos que Se lhe pagem Conhecenssias em que o dito Senhor ordena ao Senhor Bispo o Informe neste <ver folha 117> [f. 119v-120]

267) Lixboa 23 de Março de 1730 Sobre o Senhor Bispo não por na Igreja da Ilha de Santa Catherina por Parocho o Padre Frei Agostinho, e fazer vigario ao Padre Francisco Justo Santiago [f. 120-120v]

268) Lixboa 24 de Março de 1730 Sobre a Igreja do Bom Jhesus do Iguape e Nossa Senhora da Lús dos Pinhaez do Curitiba que o Senhor Bispo pos em Concursso [f. 120-121]

269) Lixboa 28 de Abril de 1730 Sobre os Sacerdotez Secularez e Regullares que Se intromentem em Solicitar causas e demandas adquirindo por empenhos os despachoz dos Menistroz [f. 121]

270) Conta que deo o Senhor Bispo a Sua Magestade do vezitador que mandava para a Colonia e morreo antes de embarcar [f. 121-121v] 
271) Conta que deu o Senhor Bispo a Sua Magestade Sobre rezarem os Conegos em outra Igreja pella mudanssa da Sé [f. 121v-122]

272) Lixboa 8 de Agosto de 1730 Sobre a conta que derão os oficiaes da Camera da Cidade de São Paulo a Sua Magestade das desordenz que ocasionou nas Minaz do Cuybá o Padre Francisco Justo natural de Pernambuco [f. 122-122v]

273) Lixboa 18 de Agosto de 1730 Sobre os Menistroz e Oficaes da justissa Ecclesiástica Levarem mayorez Salarioz do que pela Ley estão taixadoz [f. 122v-123]

274) Lixboa 20 de Novembro de 1730 Sobre a desordem que houve na Igreja Matriz da Cidade de São Paulo o vigário da Igreja e da Vara não quererem que a Camara tomasse asento junto do arco da Capela Mor em dia de Corpo de Deos [f. 123]

275) Lixboa 31 de Janeiro de 1731 Sobre a quantidade de Donativo que Se havia de dar nesta Cidade por occasião dos Reaes Cazamentoz em varioz generoz [f. 123v]

276) Carta do Secretário do estado escrita ao Senhor Bispo avizando o Sobre um negro que Se prendeo de noyte que andava armado Escravo do Vizitador Manoel Ferreira Batalha e o vigário da Igreja Jose Nogueira o tirara das maoz da justissa [f. 123v-124]

277) Carta que escreveo o Secretario de Estado ao Senhor Bispo dando-lhe parte das pertubaçoenz e desturbios que tem cauzado Manoel Ferreira Batalha vizitador na Comarca do Rio das Mortez ao povo [f. 124-124v]

278) Resposta do Senhor Bispo ao Secretario de Estado Sobre as queixaz do Vizitador Manoel Ferreira Batalha e do Vigário Jose Nogueira Ferraz [f. 124v-125]

279) Lixboa 20 de Fevereiro de 1731 Sobre os Parochoz fazerem aSentos nos Livros das Parochias dos defuntos e dos testamentoz e < dos Bautismoz> para o Juizo dos auzentes Recadarem os benz dos que morrem abintestadoz <ver folha 112 folha 135> [f. 125-125v]

280) Carta do Secretário de Estado ao Senhor Bispo em que lhe aviza que o Vigário da Vara do Rio das Mortes mandara Excomungar ou Com pena de Excomunhão notificar as Mezas das Confrariaz [f. 126]

281) Lixboa 9 de Junho de 1731 Sobre os ornamentoz para as Igrejas que Serão obrigadas os Parochos fazerem Requerimento a Sua magestade [f. 126]

282) Lixboa 7 de Julho de 1731 Sobre haver na freguesia da Villa da Laguna hum Vigario Collado [f. 126v]

283) Lixboa 11 de Janeiro de 1732 Sobre os Parochos Levarem pelos escravos que morrem tres e quatro oitavos e a vella por cada hum [f. 126v]

284) Lixboa 15 de Fevereiro de 1732 Sobre o Vigario dos Goyasez Pedro Ferreira Brandáo levar des oytavas de cada pessoa que morre abintestados e das inquietaçoens que cauza naquellas Minaz [f. 127]

285) Lixboa 16 de Fevereiro de 1732 Em que Sua magestade ordena ao Senhor Bispo lhe mande huma Lista dos Clerigos que hé necessario para as Igrejas das minaz pela grande pertubação que fazem nellas pella mesma quantidade que Se achão nellas [f. 127-127v] 
286) Lixboa 18 de Fevereiro de 1732 Sobre o Vigario da Matris do Cuyabá Levar de conhecimento pella desogriga da Quaresma de cada huma pessoa o oytavo de ouro Sendo de Comunhão, e não Sendo meya [f. 127v-128]

287) Lixboa 5 de Março de 1732 Alvará para Se pagar ao Padre Estevão Simoenz Manço Vigário da Ilha de Santa Catherina em mil reis da Congrua cada anno [f. 128-128v]

288) Lixboa 11 de Marco de 1732 Sobre Se Proverem as Missóens do Gentio Paracis por Serem Pacíficos [f. 128v]

289) Lixboa 21 de Março de 1732 Ordem que Sua Magestade mandou ao Senhor Bispo a Respeito da Representação que lhes fes o Thesoureiro dos defuntos e ausentes e da huma petição que lhe fes Maria Martinz para que os Menistroz Ecclesiasticos não [offendam] a jurisdição Secullar [f. 129]

290) Copia da Representação que fes o Thesoureiro dos defuntos e ausentes Constantino de Souza Costa Sobre huma herança de Maria Martins e Remessa que queria fazer e o impedio o Padre Antonio de Almeida e Vasconcelos trestamenteiro [sic] [f. 129-129v]

291) Copia da Resposta do Thesoureiro Geral da Corte aserca do acima Referido na Representação do Thesoureiro doz defuntoz E ausentez das Minas [f. 129v-130]

292) Copia da Resposta do Promottor [Procurador] geral ao mesmo propozito acima Referido [f. 130]

293) Copia da Petição que fis Maria Martinz Sobre a Sua heranssa [f. 130-130v]

294) Lixboa 22 de Março de 1732 Ordem que Sua Magestade mandou ao Thesoureiro dos ausentez Sobre Requerimento da heranssa de Maria Martinz [f. 130v-131]

295) Lixboa 22 de março de 1732 Sobre a ordem que veyo para o Senhor Bispo mandar observar e excutar na Comarca do Rio das Mortez Sobre o Juizo dos ausentes [f. 131]

296) Lixboa 23 de Março de 1732 Sobre o Requerimento que fes a Sua Magestade Duarte Teixeira [Chavez] para o Padre Manoel João [ilegivel] [corroído $40 \mathrm{~mm} \times 10 \mathrm{~mm}$ ] Seu Procurador em humas [ilegivel] [corroído $55 \mathrm{~mm} \times 10 \mathrm{~mm}$ ] nesta Cidade e que não fosse [corroído $57 \mathrm{~mm} \times 10 \mathrm{~mm}$ ] procurasse as ditaz causas [corroído $75 \mathrm{~mm} \times 10 \mathrm{~mm}$ ] [f. 131-131v]

297) Lixboa 8 de Abril de 1732 Sobre o Requerimento do Escrivão proprietário Gabriel [Francisco] Aleixo aserca de varios dinheiroz e dos ausentes [f. 131v-132v]

298) Lixboa 2 de Mayo de 1732 Sobre pedir o Caminho da Villa de Santa Catherina a Sua Magestade por Seu Vigário o Padre [Frei] Agostinho da Trindade em que ordena ao Senhor Bispo o informe [f. 132v]

299) Resposta e Informação que deu o Senhor Bispo do Padre [Frei] Agostinho da Trindade da ordem acima [f. 132v-133]

300) Lixboa 8 de Mayo de 1732 Sobre huns Religiozos que Sua Magestade mandou para a Colonia e para Se fundar hum Hospicio para elles administrarem oz Sacramentoz [f. $133-133 v]$

301) Lixboa 17[?] de Julho de 1732 Sobre que Sua Magestade ordena ao Senhor Bispo mande hum Parocho para a freguesia da Vila de Guarapary [f. 133v] 
302) Lixboa 18 de Julho de 1732 Sobre huma Representação que fes a Sua Magestade o Arcebispado [corroído $35 \mathrm{~mm} \times 10 \mathrm{~mm}$ ] que varioz [corroido $53 \mathrm{~mm} \times 10 \mathrm{~mm}$ ] hospícios e [corroído $60 \mathrm{~mm} \times 10 \mathrm{~mm}$ ] obediência [corroido $55 \mathrm{~mm} \times 10 \mathrm{~mm}$ ] [f. 133v-134]

303) Informação que deu o Senhor Bispo a Sua Magestade Sobre o Requerimento que fizerão os officiaes da Camera de Villa Rica de quererem os Parochos tivessem [corroído $5 \mathrm{~mm}$ $x 10 \mathrm{~mm}$ ] cada escravo que morresse duas oitavaz e huma vela de quarta [f. 134v]

304) Lixboa 29 de Abril de 1733 Sobre a Publicação da Provizão de Sua Magestade aos Parohos para a Recadação dos bens dos defuntos e ausentez < Ver folha 112; e folha 125> [f. 135]

305) Lixboa 23 de Mayo de 1733 Sobre Se mandar vir das minaz os Clerigos que não forem necessários e Senão Consentir que vão a Maz pela mesma quantidade que nellas Se achão [f. 135-135v]

306) Lixboa 8 de Junho de 1733 Sobre pedir a Camera da Vila de Itú a Sua Magestade quem lhes administrasse os Sacramentoz aos moradores delas [f. 135v]

307) Copia da Reprezentação que fizerão a Sua Magestade os officiaes da Camera da Vila de Itú Sobre a grande necessidade que tinhão de quem lhes administre os Sacramentos aos ditos moradores [f. 136]

308) Lixboa 18 de junho de 1733 Sobre Levarem os Parochos muitos pellas esmollas das missas dos escravoz que morrem nas Minas e de o enterrarem [f. 136-136v]

309) Lixboa 8 de Julho de 1733 Sobre que Recomenda Sua Magestade ao Senhor Bispo fassa Sahir Logo do Seu Bispado ao Padre José Ribeiro Diaz pella grande desinquietação e disturbio que faz nelle [f. 136v-137]

310) Lixboa 17 de Julho de 1733 Sobre Se dar ao Vizitador que fosse para a Collonia oytenta mil reis para a ajuda de Custo por esta ves Somentes [f. 137]

311) Lixboa 24 de Julho de 1733 Sobre hum Parocho para a villa da Laguna pella Reprezentação que fes o Capitam Mor da dita Villa a Sua Magestade [f. 137-137v]

312) Carta que escreveo ao Senhor Bispo Sobre a vesita que fes em São Paulo Frei Luis de Santa Rosa Religiozo de Santo Antonio [f. 137v-138]

313) Copia da carta que foy para a Meza da Consciencia Sobre as Religoens e Missoenz e de lle darem obediência os Religiozoz dellas [f. 138-138v]

314) Copia da ordem que ElRey Dom Felippe mandou passar E ordenar para as Congruas das Sés e freguezias deste [ilegivel] Brasil de 23 [corroído $10 \mathrm{~mm} \times 10 \mathrm{~mm}$ ] de [corroido $50 \mathrm{~mm} \times 10 \mathrm{~mm}$ ] [f. $138 \mathrm{v}-139 \mathrm{v}$ ]

315) Lixboa 30 de Setembro de 1733 Alvará Sobre a Licenssa da mudanssa da Sé para a Igreja da Crus que dá Sua Magestade [f. 139v-140v]

316) Alvará porque Sua Magestade foi Servido de erigir na Sé de São Sebastiam desta Cidade mais quatro [Predios] das trés com o titulo de Conesias Magistral Doutoral e Penitenciaria e a quarta de Se dividir em dous meyos cônegos < Registro e Provizão porque foi [corroido $15 \mathrm{~mm} \times 10 \mathrm{~mm}$ ] lhe Servido confirmar a Remissão do foro de dezesseis tostoins que 
Se achava [ilegivel] posto nos chãos que [ilegivel] o Ilustríssimo Bispo o Ignacio [corroído $10 \mathrm{~mm} \times 10 \mathrm{~mm}$ ] hum titulo [corroido $15 \mathrm{~mm} \times 10 \mathrm{~mm}$ ] vai a folha [ilegivel] $>$ [f. 141-142]

317) Alvará em que Sua Magestade accrescenta a Congrua ao deão e mais dignidadez da Sé desta Cidade de São Sebastiam [f. 142-143]

318) Alvará em que Sua Magestade ha por bem accrescentar em dobro os ordenadoz ao Provizor e vigario geral deste Bispado [f. 143-143v]

319) Alvará Sobre o accrescentamento em dobro da Congrua da ordinaria da Sachristia da Sé deste Bispado para despesa de vinho hostiaz e o mais necessário [f. 143v-144]

320) Lixboa 20 de Outubro de 1733 Em que Sua Magestade aviza ao Senhor Bispo dos novoz accrescentamentos que fes em dobro as Congruaz do Cabido Deão Conegos e mais Menistroz e da Sachristia [f. 144-144v]

321) Lixboa 20 de Outubro de 1733 Sobre que Sua Magestade Recomenda ao Senhor Bispo que ponha ao Padre José Mathiaz de Gouvea por Vigario de huma das quatro Igrejas de mais Rendimento das Minaz por elle ter Collado em huma dellaz [f. 144v-145]

322) Lixboa 27 de Outubro de 1733 Sobre a mudanssa da Sé para a Igreja da Cruz de que [Corta] do Alvara que ja Se passou ficando Sempre hum Capellão na outra Sé para diser missas [f. 145-145v]

323) Lixboa 21 de Março de 1734 Sobre a capitação dos Escravos das Minaz que Sua Magestade mandou por nas Minaz e pedio ao Senhor Bispo huma lista de todoz oz Parochoz e vigarios da vara que Se achão nas minaz [f. 145v-146]

324) Copia da Carta que o Senhor Bispo escreveo a Sua Magestade aserca do Capelão para a Sé velha e de Se arbitrar congrua para a fabrica della [f. 146-146v]

325) Copia da Reprezentação que fes o Senhor Bispo a Sua Magestade Sobre a grande necessidade que havia nesta Cidade de hum Seminario para Se faser no Convento da Igreja de Nossa Senhora da Ajuda e do breve da Sagrada Congregação para o dito [f. 146v-147]

326) Lixboa 22 de Maio de 1734 Sobre a queixa que fes a Sua Magestade a Camera da Cidade de São Paulo do vigário Matheus Lourenço em dia das festas Reaes lhe não dar agoa benta com Sobrepelis e estolla como era [ilegivel] [f. 147]

327) Lixboa 22 de Novembro de 1734 Sobre a nomeação que o Senhor Bispo fes das duaz Conezias pagas Magistral e Penitenciaria em o Padre Manoel de Pinho Candido e no Padre Domingos Lopes Antunez [f. 147v]

328) Lixboa 14 de Dezembro de 1734 Sobre o modo Com que foy tirada a Imagem de São Sebastiam da Sé velha para a Igreja da Crus e tão bem Pyas e Pulpito. [f. 148]

329) Lixboa 14 de Janeiro de 1735 Sobre a Licenssa que pedio a Sua Magestade Manoel Mendez de Almeida para mandar duas filhas para o Reino para Serem Religiozas, e que Informe o Senhor Bispo Sobre esta matéria [f. 148-148v]

330) Copia da petição que fes a Sua Magestade Manoel Mendes de Almeida para Licenssa de meter suas filhas freiraz em Portugal [f. 148v] 
331) Lixboa 17 de Janeiro de 1735 Sobre a Redução do gentio Paracis e da Congrua de Secenta mil réis para o Vigário do Cuyabá e da ordem ao Provedor da Companhia para dar Religiozoz para a Missão do gentio <ver folha 149> [f. 148v-149]

332) Lixboa 18 de Janeiro de 1735 Sobre a Reforma geral que Sua Magestade mandou fazer nas Minaz Sobre os emuLimentos e Salarioz dos Parochoz e Vigários da Vara e mais Justissas [f. 149-149v]

333) Lixboa 13 de Agosto de 1735 Sobre oz Indioz Paracizez em que Sua Magestade Recomenda ao Senhor Bispo informe o melhor modo que parecer para Conservação de Suaz aldeas <ver folha $148>$ [f. 149v]

334) Lixboa 27 de Outubro de 1735 Sobre a merce que Sua Magestade fes ao Senhor Bispo da licenssa de Se fazer o Seminario nesta Cidade e juntamente a Capella que lhe pedio para elle [f. 150-150v]

335) Lixboa 24 de Novembro de 1735 Sobre a queixa que fes a Sua Magestade o Juis de Fora que foy da villa do Carmo do vigario da dita Villa dos Seuz Excessos José Simoez [f. $150 \mathrm{v}]$

336) Copia de queixa que fes a Sua Magestade o Juis de Fora da vila do Carmo do Vigário José Simoenz [f. 150v-151]

337) Lixboa 22 de Dezembro de 1735 Sobre a desistencia que fes o Padre Pedro Pereira de San Payo da Igreja de Nossa Senhora da Conceição do Sabará donde era vigário Collado e ordena Sua Magestade ao Senhor Bispo ponha a dita freguesia em Concursso [f. 151v]

338) Copia do termo da Junta que Se fes no Palacio do Excelentíssimo Senhor Governador e Capitam General Gomes Freire de Andrada, para effeito de Se Regularem os Emolumentos dos Parochoz e Salarioz dos officiaez de Justissa. [f. 152-153]

339) Lixboa 2 de Janeiro de 1736 Em que Sua Magestade Recomenda ao Senhor Bispo lhe mande uma Lista de todas as Igrejas que tem Parochoz no Seu Bispado, e das Congruaz que cada hum tem para a fabrica dellaz. [f. 153v]

340) Lixboa 17 de Janeiro de 1736 Sobre o Conego e Padre Manoel de Bastoz da Fonsseca hir para Rezidir na Sua Sé de Angolla ou dezistir da Conezia em que Sua Magestade encomenda ao Senhor Bispo o manda notificar para hir Residir na dita Sé ou fazer dezistencia da dita Conezia [f. 153v-154]

341) Lixboa 10 de Fevereiro de 1736 Sobre as Capellaz Curadaz e outraz [corroído $50 \mathrm{~mm}$ $\times 10 \mathrm{~mm}$ ] the dem os ornamentos [corroido $40 \mathrm{~mm} \times 10 \mathrm{~mm}$ ] necessarios para o Servisso [corroído $40 \mathrm{~mm} \times 10 \mathrm{~mm}$ ] os Parochoz e Capellaenz Serão obrigados a ensinar [corroído $15 \mathrm{~mm} \times$ $10 \mathrm{~mm}$ ] christãa aos meninoz e [corroído $20 \mathrm{~mm} \times 10 \mathrm{~mm}$ ] Escravoz Como Livres E os Pays de familiaz e o mais que nella Se Conthem [f. 154-155]

342) Lixboa 17 de Fevereiro de 1736 Sobre a queixa que fés a Camera de Vila Rica dos Parochoz Levarem huma grande Exorbitancia pelos escravoz que morem e pellas Conhecenssaz [f. 155-155v] 
343) Lixboa 19 de Abril de 1736 Sobre que Sua Magestade Recomenda ao Senhor Bispo Castigue ao Padre Jose da Costa pelas insolenciaz que tem feito nas minaz e ter feito Mortez e tirar um prezo das maoz da Justissa [f. 155v]

344) Resposta que mandou o Senhor Bispo a Sua Magestade aSerca da nomeação que fés das duaz Conesiaz vagas Magistral e Penitenciaria em o Padre Manoel de Pinho [Cardido] e Domingos Lopes Antunes [f. 156]

345) Conta que deu o Senhor Bispo a Sua Magestade das Capellaz que ha pelo Reconcavo de Seu Bispado das que São Curadaz ou não da necessidade que ha nellaz de ornamentos e para as fregueziaz por huma Lista que lhe Remeteo < Ver a folha 165 e folha $154 \mathrm{~V}>$ [f. 156v-157]

346) Sobre a conta, que deu o Senhor Bispo a Sua Magestade do Padre Frei Agostinho da Trindade Religiozo da ordem de Nossa Senhora do Carmo da Provincia desta Cidade [f. 157v]

347) Lixboa 7 de Outubro de 1736 Sobre Se festejar hum Nascimento de huma netta de Sua Magestade filha de Nosso Principe [f. 158]

348) Lixboa 3 de Desembro de 1736 Sobre a informação que deu o Senhor Bispo a Sua Magestade de não quererem os Irmaos da Irmandade de Santa Crúz dos Militarez que Se trasladasse a Sé para a dita Igreja [f. 158-158v]

349) Lixboa 14 de Abril de 1732 Sobre em que Sua Magestade ordena ao Senhor Bispo não deixe passar para Portugal mulher alguma Sem ordem Sua <esta ordem pertensse ao anno de 1732, junto Com hum alvará que por descuido se lanssou em este anno de 1736> [f. 158v]

350) Lixboa 10 de Março de 1732 Alvará que Sua Magestade ordena ao Senhor Bispo não deixe hir <Este Alvara pertensse a ordem asima e ao anno de 1732 que por descuido $\mathrm{Se}$ lanssa em a era de 1736> Alvará em que Sua Magestade ordena em que não vão mulherez para o Reino Sem primeiro Se averiguar as que vão para Religiosaz Se tem vontade de tomar outro estado e Sem ordem Sua [f. 158v-159v]

351) Conta que Seu o Senhor Bispo a Sua Magestade da mudanssa dos Conegos da Igreja da Cruz para o Rozario para Rezarem por estar a Igreja da Crus aRuinada e De Se procurar Lugar Suficiente para Se fazer nova Cathedral [f. 159v-160]

352) Lixboa 27 de Janeiro de 1738 Sobre o Requerimento que fes a Sua Magestade a Maria da Cruz natural de Santoz em que pedia Licenssa para Ser Religioza em Portugal e Sua Magestade ordena ao Senhor Bispo informe Com Seu parecer [f. 160]

353) Lixboa 21 de Fevereiro de 1738 Sobre Se prenderem os cleregos e Fradez que andarem pelos destritoz das minaz Sem terem ocupação em que Sua Magestade ordena tao bem ao Governador que por Comissão do Senhor Bispo o fassa [f. 160v]

354) Lixboa 22 de Fevereiro de 1738 Sobre a queixa que fes a Sua Magestade a Camera da Cidade de São Paulo do Vigário Matheus Lourenço em lhe não darem agoa benta com Sobrepelis e estolla na Igreja nas festas Reaez Como hé estyllo [f. 160v-161] 
355) Copia da queixa que fizerão a Sua Magestade os officiaes da Camera de São Paulo do vigário Matheus Lourenco de Carvalho Sobre não dar agoa benta a Camera [f. 161]

356) Lixboa 20 de Março de 1738 Em que Sua Magestade ordena ao Senhor Bispo por Em Concursso a Igreja Matris da Vila [corroído $35 \mathrm{~mm} \times 10 \mathrm{~mm}$ ] São Salvador da Ubatuba [corroido $50 \mathrm{~mm} \times 10 \mathrm{~mm}$ ] [f. 161-161v]

357) Lixboa 20 de Março de 1738 Sobre que Sua Magestade ordena ao Senhor Bispo ponha a Igreja Matriz da Vila do Sorocaba da Cidade de São Paulo em Concursso para Ser Collada com Congrua de quarenta mil réis [f. 161v-162]

358) Lixboa 9 de Abril de 1738 Sobre em que Recomenda Sua Magestade ao Senhor Bispo mande prender ao Vigário Antônio Mendez de Santiago por Ser entrado no levante do Arrayal de Sáo Romáo das Minaz e que proceda Contra elle e juntamente fassa Sahir todoz os clerigos que não tiverem ocupaçoens nas ditas Minaz [f. 162-162v]

359) Lixboa 16 de Abril de 1738 Sobre as Conezias que vagarem fazer o Senhor Bispo as nomeaçoenz em pessoas graduadaz e em falta destaz nas mais Capases que achar, Sem Se faserem Editaes para Coimbra nem Evora [f. 162v-163]

360) Lixboa 17 de Abril de 1738 Sobre a Recomendação que fes Sua Magestade ao Senhor Bispo para examinar Se Se embarcou o Padre Manoel de Bastoz da Fonsseca para Angola, e não tendo embarcado o fassa Logo embarcar para hir Residir na Sua Conesia [f. $163-163 \mathrm{v}]$

361) Lixboa 17 de Abril de 1738 Em que Sua Magestade Recomenda ao Senhor Bispo mande noteficar ao Padre Antonio Cardoso Gomes para que Se embarque Logo para a [Ilha] terceira a Residir na Sua Vigairia onde hé Collado, ou que desista della [f. 163v-163]

362) Lixboa 6 de Agosto de 1738 Sobre a Provizão que Sua Magestade mandou passar em que fazia mercê dar a Capella de Nossa Senhora do Desterro e mais benz pertencentez para Rendimento do Seminario que o Senhor Bispo quer fazer para Seminaristaz Ecclesiásticos [f. 163-163v]

363) Lixboa 11 de Agosto de 1738 Sobre que Recomenda ao Senhor Bispo Sua Magestade o Conferir Com o Governador e Brigadeiro para Lugar ou Citio Capas onde Se possa fazer nova Sé [f. 163v-164]

364) Copia da Conferencia que fisera o Senhor Bispo e o General e o Brigadeiro José da Silva Paes Sobre o lugar ou Sitio para Se fazer a nova Se Cathedral [f. 164]

365) Lixboa 15 de Dezembro de 1738 Sobre o Requerimento e petição que fes a Sua Magestade o Padre Jose Carlloz da Silva Vigário do Rio grande para Se lhe dar Congrua [f. 164v]

366) Copia da petição que fes a Sua Magestade o Padre Jose Carllos da Silva pedindo Congrua por Ser Vigário da Povoação do Rio Grande [f. 164v-165]

367) Copia da ordem que Sua Magestade mandou ao Provedor da fasenda deste Reino para dar direito para as Congruaz das Capellaz Curadaz e para ornamentoz para as Igrejas que necessitassem <Ver a folha 126 / Ver a folha 156, e 154> [f. 165] 
368) Lixboa 22 de Abril de 1739 Sobre o arbitrio que fizerão os vitadorez [sic] das Congruas das Capellas Curadaz, e dos ornamentos para as ditas em que Sua Magestade avise ao Senhor Bispo mande ordem ao Provedor para pagar ou mandar fazer os ornamentos [f. $165 \mathrm{v}]$

369) Lixboa 3 de Outubro de 1739 Sobre ordenar Sua Magestade que os Conegos e Cabbido Se Conserve na Igreja do Rozario dos Pretos athe Se fazer nova Sé, e não impedindo que os pretoz fassão nella as Suaz funssoenz, para Se evitar as queixaz que os ditoz tem feito [f. 166-166v]

370) Lixboa 18 de Fevereiro de 1740 Sobre a Recomendação que fes Sua Magestade ao Senhor Bispo para náo exceder muito do numero dos Seus ordinandoz pelo prejuizo que pode haver [f. 166v]

371) Lixboa 23 de Fevereiro de 1740 Em que Sua Magestade Recomenda ao Senhor Bispo ponha em Concursso as Igrejas que Se achão Vagas para Se proverem em Vigários Collados [f. 166v-167]

372) Lixboa 24 de Mayo de 1740 Copias de varias Provizoenz e ordens que Mandou Sua Magestade ao Provedor e Intendentez e Governador do Maranhão para Senão Entrometerem nos descobrimentoz das Minaz dos Goyases por pertencerem a jurisdição do Governador de São Paulo [f. 167v]

373) Copia da Rezolução Real que foy para o Governador do Maranhão pelos Novos descobrimentos das minas [f. 167v-168]

374) Copia da ordem que Sua Magestade mandou ao Intendente das minas Sebastiam Mendez de Carvalho Sobre aRematação que fés dos dizimos das Minas dos Goyases [f. 168-168v]

375) Capitullo de huma Carta mandada ao Reverendo Vigario da vara Domingos Vas Mourão pelo Reverendo Doutor Henrique Moreira de Carvalho Como vigário Capitullar Sede vacante [f. 169]

376) Lixboa 14 de Fevereiro de 1741 Sobre as pessoas que meresserem e forem julgadas pelo Juizo Ecclesiástico Serem presas Na Cadea publica desta Cidade por não haver Aljube [f. 169-169v]

377) Lixboa 14 de Fevereiro de 1741 Em que Sua Magestade ordenou ao Governador e Provedor da fasenda Real Se desse ao Senhor Bispo todos os annoz Sento e vinte mil réis de ajuda de custo para appozentadoria [f. 169v-170]

378) Alvará de 15 de Fevereiro de 1741 em que Sua Magestade fés mercê dar a faculdade de poder nomear as conesias e vigairariaz E mais benefícioz Ecclesiásticos que vagarem no Seu Bispado [ilegivel] por da Sua Residencia ao Senhor Bispo Dom Frei João [f. 170-170v]

379) Lixboa 2 de Março de 1741 Em que Sua Magestade Recomenda ao Senhor Bispo mande tirar humaz esmollaz para a Provincia ou Convento de São Francisco da India [f. 171]

380) Lixboa 7 de Março de 1741 Sobre Se porem em Concursso as Igrejas da Vila da Sorocaba, e a da Vila da Ubatuba E as mais que estivessem vagas para Serem Collativas [f. 171-172] 
381) Lixboa 4 de Abril de 1743 Carta do Secretário de estado da Corte que escreveo ao Senhor Bispo em Resposta da Representação que fés a Sua Magestade da desattenção que lhe fizerão os Cavalheiros das ordens Millitarez em dia da Procissão do Corpo de Deus Sendo o causador o Provedor da fasenda [f. 172-172v]

382) Copia da carta e ordem que Sua Magestade escreveo ao Governador para Reprehender ao Provedor da fasenda e o mandar prender pela desattenção que fés ao Senhor Bispo na Procissão de Corpo de Deus [f. 172v-173]

383) Lixboa 7 de Mayo de 1744 Sobre a queixa que fizerão a Sua Magestade os officiais da Camera de São Paulo pelos Exorbitantez Salarioz que Levão o Vigário da vara e mais officiaes do Ecclesiástico [f. 173]

384) Copia da Reprezentação que fizerão a Sua Magestade os officiaes da Camera da Cidade de São Paulo queixandosse dos grandes Salarioz que Levão o Vigário da vara e mais officiaes do Ecclesiástico [f. 173-173v]

385) Lixboa 8 de Mayo de 1744 Sobre a queixa que fizerão a Sua Magestade os officiaes da Camera de Pernagua dos Exorbitantez Salarios que Levão o Vigario da vara e Seus officiaez [f. 174]

386) Copia da Representação e queixa que fizerão a Sua Magestade os officiaes da Camera de Pernagua do vigário da vara Levar exorbitantez Salarios [f. 174-174v]

387) Lixboa 11 de Mayo de 1744 Sobre os officiaes de justissa fazerem Citaçoenz aos domingos e dia Santos e nas Igrejas as pessoaz estando a ouvir Missa [f. 174v]

388) Lixboa 11 de Mayo de 1744 Sobre a Representaçáo que fes a Sua Magestade a Camera desta Cidade em que os Cabbidos em dia da procissão de Corpo de Deus não hião Com capas de asperges como Era Costume [f. 175]

389) Copia da Ordem que veyo ao Governador para não impedir a que Se metao na Cadea os prezoz, Reos que forem julgadoz pelo Juizo Ecclesiástico pela falta de não haver aljube [f. 175v]

390) Copia da ordem que mandou Sua Magestade ao Senhor Governador Sobre as contendaz que tivera o Ouvidor de Vila Rica Com o Vigário da vara Sobre as Respostas de hum Recursso [f. 175v-176]

391) Lixboa 12 de Mayo de 1744 Sobre as Contendaz que teve o Ouvidor de Vila Rica Com o Vigário geral Sobre hum Recursso [f. 176-176v]

392) Lixboa 12 de Mayo de 1744 Sobre as Contendas do Ouvidor de Vila Rica Com o Vigário geral Sobre hum Recursso em que Sua Magestade mandou prender o dito Ouvidor [f. 176v-177]

393) Lixboa 18 de Mayo de 1744 Em que Sua Magestade Recomenda ao Senhor Bispo as esmollaz para o Convento de São Francisco da India [f. 177-177v]

394) Lixboa 21 de Mayo de 1744 Sobre os Ouvidorez e Juizes da Coroa não Responderem aos aggravos dos procedimentoz da Justissa Ecclesiástica com demoraloz [f. 177v] 
395) Copia da Carta do Secretário de estado Escrita ao Governador para prender o ouvidor pela desatenção que fés ao Senhor Bispo e outros desturbios maiz do Povo [f. 177v-178]

396) Lixboa 30 de Novembro de 1744 Em que Sua Magestade manda ao Senhor Bispo o informe Sobre o Requerimento da Petição do Padre Dom Ignacio Bercainho Monteiro de querer Ser Vigário Collado da Igreja de Santa Anna da Vila Boa dos Goyazes [f. 178-178v]

397) Copia da petição do Padre Dom Ignacio Biscainho Monteiro para Ser Vigário Collado na Igreja de Santa Anna dos Goyasez [f. 178v]

398) Lixboa 29 de Abril de 1746 Sobre os Exorbitantez que levao nesta Cidade no Juizo Ecclesiástico por custoz e mais asignaturas de que Se queixou a Camera [f. 179]

399) Lixboa 6 de Mayo de 1746 Sobre a nomeação que fes Sua Magestade de Bispo para a Cidade de São Paulo e dividido deste Bispado <alias sobre Se carregarem os papeis da Camera pertencentes a São Paulo> [f. 179-179v]

400) Lixboa 7 de Mayo de 1746 Em que Sua Magestade manda que informe o Senhor Bispo Se na Sua Diocese São precizaz mais Igrejas para Se administrarem os Sacramentos [f. 179v]

401) Lixboa o $1^{\circ}$ de Mayo de 1747 Em que Sua Magestade ordena ao Senhor Bispo mande entregar oz papeis e documentos pertencerem ao Bispo da Cidade [f. 179v-180]

402) Lixboa 6 de Mayo de 1747 Provizão para Se pagar a Congrua do Senhor Bispo desde o tempo e o dia em que Sua Magestade o Confirmou de um Conto de réis cada anno oitocentos réis para elle oitenta réis para esmollaz e cento e vinte réis para Congruas de Seus officiaez [f. 180-180v]

403) Lixboa 7 de Mayo de 1747 Provizão em que Sua Magestade ordena Se pagou ao Senhor Bispo todoz annos enquanto não mandar o Contrario dous mil Crusadoz cada hum anno [f. 180v-181]

404) Lixboa 7 de Mayo de 1747 Provizão em que Sua Magestade manda Se de todoz annos Sento e vinte mil réis para ajuda de custo e para a aposentadoria das Cazas em que vive o Senhor Bispo [f. 181-181v]

405) Carta do Secretario de Estado escrita ao Senhor Bispo para mandar Capelaens para as fortalezas da Ilha de Santa Catherina e para algunz Presidioz para administrarem oz Sacramentos aos Soldados e mais moradores pelo Requerimento do Brigadeiro José da Santa Sa 26 Paes. [f. 181v]

406) Lixboa 26 de Agosto de 1747 Em que Sua Magestade ordena ao Senhor Bispo lhe Remeta todos os Concurssos que fizer das Igrejas que estiverem vagas, e juntamente lhe dê Conta de todos os beneficios e Conezias da Sé que vagarem pelo Tribunal da Mesa da Conssiencia [f. 182]

407) Lixboa 9 de julho de 1747 Ordem em que Se concede ao Senhor Bispo faculdade para poder nomear as dignidades e conesiaz e vigairariaz benefícios, e mais Cargos Eccle-

\footnotetext{
${ }^{26}$ Essa abreviatura pode ser Santa, Souza ou Silva.
} 
siasticos do Bispado estando nelle Residente Excepto a dignidade de Deão que hé Reservada ao dito Senhor [f. 182v-183]

408) Copia da Carta que escreveo o Cabido da Sé desta Cidade pedindo a Sua Magestade ornamentos para a dita Sé de 8 de Agosto de 1746 [f. 183-183v]

409) Ordem que Mandou Sua Magestade ao Senhor Bispo e pelas mais Comarcas das Minas para Se fazer junta de Menistros e Letrados nos Recursos da Coroa de 4 de Septembro de $1748<$ A ordem pertence a esta informação acima não se Registar por não ser necessária.> [f. 183v]

410) Lixboa 9 de novembro de 1749 Ordem que Sua Magestade mandou para Se dividir as Igrejas de Sé e Candelaria em quatro Parochias pelos limites que asignar o Senhor Bispo [f. 184v]

411) Lixboa 9 de novembro de 1749 Ordem que Sua Magestade mandou para Serem acrescentadas as Congruas das Igrejas deste Bispado que São Coladas em mais Sento e Sincoenta mil para Com Sincoenta que tem ficarem em duzentos mil reis [f. 185]

412) Requerimento que Se fes por petição Sobre os Parochos das freguesias desta Cidade a Sua Magestade para que Se [Collem] com a Congrua de duzentos mil reis [f. 185v]

413) Ordem que Sua Magestade mandou para o Senhor Bispo informar com o Seu parecer Sobre o Requerimento dos Parochos das freguezias deste Reconcavo Sobre Serem Colladas as Suas Igrejas Com o acrescentamento da Congrua de duzentos mil réis de 11 de novembro de 1749 [f. 185v]

414) Ordem em que Sua Magestade ordena ao Senhor Bispo para o informar Sobre o Cittio que eleger para Se erigirem duas Igrejas proprias para Servirem de freguesia da divisão da Candelaria e Sé, e o Custo farão e da fabrica que necessitarem e quem deve Concorrer para huma e outra despesa [f. 186]

415) Ordem em que Sua Magestade ordena ao Senhor Bispo para por em Concursso a Igreja de Cabo Frio Com o acrescentamento da Congrua de dusentos mil réis [f. 186-186v]

416) Ordem Sobre a conta que deu o Senhor Bispo das Minas a Sua Magestade a Respeito das Cauçóens Chancelarias e mais emolumentos que o Senhor Bispo deste Bispado tinha e que lhe pertenssão e que Rezolvesse o dito Senhor Bispo a quem pertencião por escuzar de mandar e do que Sua Magestade ordena [f. 186v]

417) Copia da carta e queixa que fes a Sua Magestade o Padre vigário da Igreja de Sáo João da Praya Pedro Marques Durão Sobre o Padre missionario Angelo de Siqueira em que tirava esmolas com violência [f. 188v-187]

418) Ordem em que Sua Magestade fás merce ao Senhor Bispo de lhe dar todo o destrito do Sul desde o Rio de São Francisco athé a Colonia do Sacramento e ficar Sugeyto ao Seu Bispado [f. 187]

419) Copia da Reprezentação ou Carta que fes a Sua Magestade a Camera desta Cidade Sobre hirem todas as Religioens acompanharem a procissão do Corpo de Deus e assim mais todas as Confrarias e Irmandadez [f. 187-187v] 
420) Ordem em que Sua Magestade ordena ao Senhor Bispo informe Com Seu parecer Sobre o Requerimento que fizerão os oficiaes da Camera desta Cidade a Respeyto de acompanharem todas as Religioens e Confrarias a procissão do Corpo de Deus [f. 187v]

421) Copia da carta e queixa que fes o vigario o Padre Pedro Marques [Durão] da freguesia de São João da Praya Sobre o Padre Missionario Angelo de Siqueira cuja Copia veyo de Lixboa com ordem de Sua Magestade a Vossa Excelência Reverendíssima. [f. 187v-184]

422) Ordem em que Sua Magestade ordena ao Senhor Bispo lhe informe com Seu parecer na petição e Requerimento do Padre Pedro Marques Durão vigario da freguesia de São João da Praya de Campos dos Goytacazes [f. 184]

423) Lixboa 4 de dezembro de 1749 Ordem e Provizão que Sua Magestade mandou ao Senhor Bispo Sobre o acrescentamento das Congruas dos Parochos das Igrejas que São Coladas para se lhe Satisfazer pela fazenda Real e fazer asento na Provedoria [f. 184v]

424) Alvará que Sua Magestade foy Servido accrescentar as Congruas as quatro dignidades e maiz Conegos e meyos Conegos da Sé deste Bispado do Rio de Janeiro na forma que nelle Se conthem de 14 de Dezembro de 1749 [f. 185-185v]

425) Provizão em que Sua Magestade ordena para Se pagarem as Congruas acrescentadas as Dignidades do Cabbido da Sé deste Bispado pela fazenda Real e para Se fazer asento na Provedoria da fazenda Como nella Se conthem [f. 185v-186]

426) Provizão por que Sua Magestade há por bem fazer Merce ao Bispo do Rio de Janeiro de que se possa juntar Naquella Cidade hum Mosteiro de Trinta e tres Religiozas, com o Statucto e Observancia [corroído $5 \mathrm{~mm} \times 10 \mathrm{~mm}$ ] da Madre de Deoz desta Cidade de Lisboa $<$ e como assima se declara> [f. 186-187]

427) Carta em que Sua Magestade mandou ao Senhor Bispo avizando do falecimento Del Rey Nosso Senhor Dom João quinto e para Se fazerem os funeraes de 5 de Agosto de 1750 [f. 187]

428) Alvara que Sua Magestade foy Sirvido Conceder Mais três Capeláens para o Coro da Sé desta Cidade para Com os nove que já tem fazerem o numero de doze Capeláens [f. $187-187 \mathrm{v}]$

429) Ordem que Sua Magestade mandou ao Senhor Bispo em que lhe ordena que todas as dependencias como São queixas de Parochos provimento de Igrejas paramentos para dias fabricas Reedificaçôens Congruas novas Oraçoens Sejão Remettidas pela Meza da Consiencia e não para ultramarino. [f. 187v-188]

430) Treslado de huma ordem que Sua Magestade mandou aos oficiaes da Camera desta Cidade em que ordena que o Cabbido da Sé deste Cidade dem Duttos aos officiaes da Camera quando asistirem emcorporados nas festas Reaiz vinda em 19 de Fevereiro de 1719 [f. $188 \mathrm{v}]$

431) Traslado da Ordem e Carta que Sua Magestade Mandou ao Provedor E maiz Irmãos da Meza da Mizericordia desta Cidade Sobre os Senhores Bispo Vizitarem a Igreja 
Altares e maiz pertencente ao culto Divino de 17 de Março de 1704 e 7 de Julho de 1722 [f. 189]

432) Traslado da Ordem que Sua Magestade mandou ao Senhor Bispo de Sáo Paulo Sobre por [huns] Parochos na Ilha de Santa Catherina para administrar o pasto Espiritual aos novos povoadores della [f. 189v]

433) Copia do Alvará que Sua Magestade mandou passar para Serem Expulssados fora de Seus Reynos todos os que Se forem ordenar com Reverendas falssas e ficarem desnaturalizadoz de todas as honras privilegioz E maiz izencôens em 26 de Março de 1746 [f. 190]

434) Copia da Provizão Sobre os Dizimos que Se achao Registrado digo que Se acha Registrada em Vila Boa de goyas na ouvidoria geral [f. 190-191]

435) Copia da ordem de Sua Magestade Sobre os Salarioz dos oficiaes Seculares do Juizo Ecclesiástico da Cidade de Pernambuco, que Se acha Registada no livro do Registo das ordens Reaes que Serve na ouvidoria do Crime e Civel de Pernambuco cuja ordem Se acha no dito Livro a folha 27 verso e folha 28 [f. 191-191v]

436) Copia de huma ordem de Sua Magestade per donde Se manda que na devasa geral Se perguntem pelos excessoz doz Salarioz e Custas que Levão os Leygos que Servem no Juizo Ecclesiastico a qual ordem Se acha Registada no livro dos Registoz, das ordens Reaes com o número Sinco da ouvidoria e Correyção desta Cidade _ a folha 20 [f. 191v-192]

437) Copia da Carta de Sua Magestade mandada e escrita ao Procurador da Coroa da Cidade da Bahia Sobre a queixa que havia feyto ao mesmo Senhor o Ouvidor geral e Provedor da dita Comarca do Senhor Arcebispo da dita Cidade Levar Lutuoza a todoz os clerigos ainda aquelles que não erão Parochoz ou Beneficiadoz e tambem aos clerigos Simples e de prohibir de Se poder uzar nas festas das Igrejas doz Santoz Sem Provizão Sua e Levar a penção 2500 réis como também Sobre os Selarioz exorbitantes ao Juízo Ecclesiástico Cuja Carta Se acha Registada no livro verde tomo primeiro que veyo da Relação da Bahia para esta desta Cidade e Se acha Registada no dito Livro a folha 148 verso [f. 192-192v]

438) Copia da ordem de Sua Magestade mandada ao Senhor Arcebispo da Bahia Sobre a carta que o dito Senhor Arcebispo lhe tinha escrito de o quererem privar do privilegio que tinha de ter aSouge Separado do do $[s i c]$ Secular e de querer Levar Luttuozas dos clérigos Simples e que nenhum cantase em festas particulares Sem Licensa do Mestre da Capela e que todos estes [pontos] Se dividirem pelo Juiz competente a quem pertencia que era o Summo Pontifice e não pelos Menistros Seculares e que queria Recorrer a Suma Cabeça da Igreja para Se findar o dito pleyto, cuja ordem e Provizão Se acha Registada no livro verde tomo primeiro que veyo da Relação da Bahia para a dicta Cidade a folha 199 verso [f. 192v-193]

439) Alvará porque Sua Magestade houve por bem crear e Erigir de novo em vigairaria Colada a Igreja de Santa Ritta desta Cidade do Rio com o Territorio e destrito que Se desmembrou por ordem do mesmo Senhor da freguesia da Candelaria desta Cidade com a Congrua de duzentoz mil réis annualmente e pagos pela fazenda Real desta Cidade [f. 193-193v] 
440) Alvará porque Vossa Magestade há por bem Criar e Erigir de novo o curato da Sé do Bispado do Rio de Janeiro de natureza Collativa Com a Congrua de duzentos mil réis annualmente pagos pela Real Fasenda [f. 193v-194]

441) Alvará porque Sua Magestade houve por bem Crear e erigir de novo em vigayraria Colada a Igreja de São Jozé desta Cidade com o territorio e destrito que Se desmembrou per ordem do mesmo Senhor da freguesia da Sé da mesma Cidade do Rio de Janeyro com a congrua de duzentoz mil réis annualmente pagos pela fazenda Real desta Cidade [f. 194-194v]

442) Ordem de Sua Magestade na qual ordena ao Senhor Bispo ponha a Concurso as Igrejas de Campo grande da Ilha do Governador Capitania do Espírito Santo Porto Seguro Rio das Caravellas e as maiz do Reconcavo desta Cidade as que São amoviveiz - [f. 195]

443) Copia da ordem que Sua Magestade mandou ao Senhor Bispo em que lhe ordenava puzese as Igrejas o Concurso as do Campo Grande Ilha do Governador Capitania do Espírito Santo Porto Seguro e todas as maiz do Reconcavo que São amoviveiz pasada em 23 de março de 1751 [f. 195-195v]

444) Copia da ordem de Sua Magestade pela qual insinua a forma que Se ha de observar nos Concursoz das Igrejas que Se puzerem vagas deste Bispado por falecimento dos Seus ultimos posuidorez como nella Se declara [f. 196-196v]

445) Copia de huma carta que escreveo o Illustríssimo Secretário de Estado da Cidade de Lixboa ao Senhor Governador do Rio de Janeyro em 10 de Setembro de 1725 [f. 197]

446) Copia da ordem digo da Copia da ordem que Sua Magestade mandou para o Senhor Governador e Capitam geral do estado do Maranhão do $1^{\circ}$ de Junho 1724 Sobre o tratamento que se havia dar ao Senhor Bispo daquelle estado [f. 197]

447) Copia da copia [sic] da ordem que Sua Magestade Mandou ao Governador do estado do Maranhão Sobre quando asistise em alguma Igreja daquelle Bispado fose em algum Lugar totalmente o culto Sem destinção tendo algum impedimento de doença [f. 197]

448) Copia para o Governador do estado do Maranhão que Sua Magestade foy Servido Rezolver Sobre o Lugar que Se havia dar ao Senhor Bispo na junta das Miçoens [f. 197]

449) Copia da Carta do Secretário do estado para o Governador e Capitam geral do Maranhão [f. 197v]

450) Copia da Carta do Secretário do estado para o Governador do Maranhão [f. 197v]

451) Copia da Carta do Secretário do estado para o Governador do estado do Maranhão - Sobre o lugar que Se deve dar ao Senhor Bispo - [f. 198]

452) Copia <da Copia > da ordem que Sua Magestade mandou ao Sennado [sic] da Camera da Cidade de Belem do Gram Pará Sobre quando forem asistir a alguma festa que não haja Cadeira e So hum banco coberto [f. 198]

453) Copia <da Copia $>$ da ordem de Sua Magestade que foy para o Ouvidor da Capitania do Gram Pará Sobre a Reverencia que Se deve ter ao Senhor Bispo daquelle Bispado [f. $198-198 v]$ 
454) Traslado de huma ordem que Sua Magestade mandou ao Senhor Bispo de Angola Sobre não Se porem Cadeyras de espaldas nas Igrejas e observarse o ceremonial Romano Cuja ordem Se tirou por Certidáo da propria que esta em Angola [f. 198v]

455) Ordem que Sua Magestade mandou ao Senhor Bispo Sobre [corroído $5 \mathrm{~mm} \times 10 \mathrm{~mm}$ ] Requerimento que féz o Padre Pedro Marque Durão vigario da Igreja de São João da Praya [f. 199]

456) Copia da ordem Sobre a desestencia que féz o Padre Pedro Marques Durão da Igreja em que era vigário Colado de São João da Praya e para o Senhor Bispo a nomear em algum Sugeyto que lhe parecese mais digno para Ser colado na dita Igreja [f. 199]

457) Alvará porque Sua Magestade há por bem criar e erigir em nova vigairaria Colada a Igreja de Maricá do Reconcavo deste Bispado do Rio de Janeyro com a congrua de duzentos mil réis annualmente paga pella Real fazenda da mesma Capitania do Rio de Janeiro [f. $199 \mathrm{v}]$

458) Alvara porque Sua Magestade houve por bem criar e Erigir em nova vigairaria Colada a Igreja de Sacorema deste Bispado do Rio de Janeiro com a congrua de duzentos mil réis annualmente paga pela Real fazenda, da mesma Capitania na forma que nelle Se conthem- [f. 199v-200]

459) Alvara porque Sua Magestade houve por bem crear e Erigir em nova vigairaria Collada a Igreja de Guaraparim deste Bispado do Rio de Janeiro com a côngrua de dusentos mil réis annualmente paga pela Real da Fasenda da mesma Capitania da forma Seguinte [f. 200-200v]

460) Alvara por Sua Magestade ouve por bem criar e Erigir em nova vigairaria Collada a Igreja de Sáo Nicolao de Suruhy deste Bispado do Rio de Janeiro com a Congrua de duzentos mil Reis annualmente paga pella Real fasenda da mesma Cappitania na forma que nelle Se contem [f. 200v-201]

461) Alvara porque Sua magestade ouve por bem crear e erigir em nova vigairaria collada a Igreja de São João Montes [?] deste Bispado do Rio de Janeiro com a Congrua de Sua Magestade digo a congrua de dusentos mil réis annualmente pago pela Real Fasenda da mesma Cappitania o Seguinte [f. 201v]

462) Alvara porque Sua Magestade ouve por bem crear e erigir em nova vigairaria collada a Igreja de São João Montes [?] deste Bispado do Rio de Janeiro Com a Congrua de dusentos mil réis digo a Igreja de Campo grande do Bispado Rio de Janeiro com a congrua de dusentos mil réis annualmente paga pela Real Fazenda de mesma Capitania o Seguinte. [f. 202]

463) Alvara porque Sua Magestade ouve por bem Criar Erigir em nova vigairaria Collada a Igreja do Pilar no Sitio dos [ilegivel] deste Bispado do Rio de Janeiro Com a Congrua a duzentos mil [corroído $5 \mathrm{~mm} \times 10 \mathrm{~mm}$ ] annualmente paga pella Real Fasenda daquela Capitania o Seguinte [f. 202-202v] 
464) Alvara porque Sua Magestade houve por bem Criar e Erigir em nova Vigairaria Collada a Igreja de Santa Crus do Reconcavo do Rio de Janeiro digo Reconcavo do Bispado do Rio de Janeiro com a Congrua de duzentos mil reis annualmente paga pella Real fazenda daquela Cappitania o Seguinte [f. 202v-204]

465) Alvara porque Sua Magestade houve por bem Crear e erigir Em nova Vigairaria Collada a Igreja de Nossa Senhora da Conceiçáo do e Alferes do Reconcavo do Bispado do Rio de Janeiro com a Congrua de duzentos mil reis annualmente paga pella Real fasenda da mesma Cappitania [f. 204-204v]

466) Alvará porque Sua Magestade há por bem Crear e erigir em nova Vigairaria Collada a Igreja de São Joáo de Tocantins no Citio de goyazes do Bispado do Rio de Janeiro Com a Congrua de duzentos mil reis annualmente paga pella Real fazenda da mesma Cappitania [f. 204v-203]

467) Alvará porque [corroído $3 \mathrm{~mm} \times 10 \mathrm{~mm}$ ] houve por bem Crear e erigir em nova vigairaria Collada a Igreja da Ilha do Governador do Reconcavo do Bispado do Rio de Janeiro Com a Congrua de duzentos mil reis annualmente paga pella Real fazenda da mesma Cappitania [f. 203-203v]

468) Treslado do Alvará porque Sua Magestade houve por bem Crear e Erigir em nova Vigairaria Collada a Igreja de São Sebastiam de Taipú do Bispado do Rio de Janeiro Com a Congrua de duzentos mil réis annualmente paga pella Real fazenda da mesma Cappitania [f. 203v-205]

469) Alvará porque Sua Magestade há por bem Criar e erigir em nova Vigairaria Collada a Igreja Collada digo Collada a Igreja de [corroído $70 \mathrm{~mm} \times 7 \mathrm{~mm}$ ] do Reconcavo do Bispado do Rio de Janeiro [corroído $80 \mathrm{~mm} \times 10 \mathrm{~mm}$ ] annualmente paga pella Real fazenda [corroído $60 m m \times 10 m m$ ] [f. 205-205v]

470) Alvara porque Sua Magestade há por bem Crear e eregir em nova [ilegível] Colada a Igreja de São Salvador do mundo de Guarati digo de Capivari do Bispado do Rio de Janeiro Com a Congrua de [ilegivel] mil reis annualmente paga pella Real fazenda da mesma Cappitania [f. 205v-206]

471) Alvara porque Sua Magestade há por bem Crear e erigir em nova Vigairaria Collada a Igreja da Santissima Trindade do Bispado do Rio de Janeiro Com a Congrua de dusentos mil réis annualmente paga pella Real fazenda da mesma Cappitania [f. 206-206v]

472) Alvara porque Sua Magestade há por bem Crear e erigir em nova vigairaria Collada a Igreja de São Salvador do Mundo [ilegível] Com a Congrua de duzentos mil reis annualmente paga pella Real fasenda da mesma Cappitania [f. 206v-207]

473) Alvará porque Sua Magestade há por bem Crear e erigir em nova Vigairaria Collada a Igreja de Nossa Senhora da piedade Inhomerim do Bispado do Rio de Janeiro Com a Congrua de duzentos mil Reis anualmente paga pella Real fazenda da mesma Cappitania [f. 207-207v] 
474) Alvará porque Sua Magestade há por bem crear e Erigir em nova vigairaria collada a Igreja de Nossa Senhora da Concepção de Corixas comarca de goyases Com a Congrua de ducentos mil réis annualmente pagos pela Fasenda Real [f. 207v-208]

475) Alvará porque Sua Magestade ha por bem crear E erigir em nova vigairaria collada a Igreja de Nossa Senhora do Desterro de Tamby Com a congrua de Sua Magestade, digo Com a Congrua de duzentos mil réis annualmente pagos pela Fazenda Real [f. 208-208v]

476) Alvará pelo qual houve Sua Magestade por bem crear e erigir em nova Vigairaria Colada a Igreja de Danta [?] comarca de Goyás deste Bispado do Rio de Janeyro com a congrua de duzentos mil réis cada anno pagos pela Sua Real Fazenda [f. 208v-209]

477) Alvará porque Sua Magestade houve por bem crear e erigir a Igreja de Nossa Senhora da Pina de Porto Seguro em nova Vigairaria Colada com a congrua de dusentoz mil réis annualmente pagos pela Sua Real Fazenda [f. 209]

478) Alvará porque Sua Magestade houve por bem crear e erigir em nova Vigairaria Colada a Igreja de Nossa Senhora da Guia de Pacobaiba com a Congrua de duzentos mil réis cada anno paga pela fasenda Real desta Cidade do Rio de Janeiro [f. 209v]

479) Alvará porque Sua Magestade houve por [bem] de crear e Erigir em Nova Vigayraria Collada a Igreja de Nossa Senhora da Piedade do Aguasú deste Bispado com a congrua de duzentos mil réis paga pela Sua Real fazenda desta Capitania [f. 210]

480) Alvará porque Sua Magestade houve por bem crear e erigir em nova Vigairaria Colada a Igreja da Paraiba do Reconcavo deste Bispado do Rio de Janeiro com a congrua de dusentoz mil réis annualmente pagos pela Sua Real faSenda desta mesma Cidade [f. 210-210v]

481) Ordem de Sua Magestade porque determina que o Reverendo Deão e Cabido da Se desta Cidade venção depois de fallecidos mais hum anno de Suas cóngruas. [f. 210v-211]

482) Registo de huma Provizão de Sua Magestade pela qual concede que o Reverendo Deão Cabido e Conego da Se desta Cidade despois de fallecidos venção hum anno de Suaz côngruas [f. 211-212]

483) Alvará porque Sua Magestade há por bem erigir e crear em nova vigararia a Igreja de Marapicu do Reconcavo desta Cidade com a Congrua de dusentoz mil reis- [f. 212-212v]

484) Alvará Em que Sua Magestade hé servidó crear de Novo na Sé desta cidade huma nova Conezia aque onde Annexo O curato da mesma Sé [f. 212v-213]

485) Ordem de Sua Magestade pela qual Se Recomenda a Sua Excelência Reverendíssima que Remetta presos para a Cidade de Lisboa a todos os Religosos transitados que Se acharem neste Bispado [f. 213-213v]

486) Alvará porque sua Magestade há por bem Crear e erigir Em nova Vigairaria Collada a Igreja de Santa Cruz, da Comarca de Goyaz com a congrua de duzentos mil reiz [f. 213v-214]

487) Carta de Sua Magestade, participando a Sua Excelência Reverendíssima a noticia do casamento da Sereníssima Senhora Princeza do Brazil com o Infante Dom Pedro [f. 214-214v] 
488) Ordem que fez ao Senhor Bispo de Angola Sobre o Senado da Camera ter Cadeira de Ezpalda na Sé; os Capitaenz Morez Nas Igrejaz da Suaz Capitaniaz na Capella Mor e dar Se lhê o Livro dos Evangelhos o baixar pello Diácono, e este na ocasião de incensar Sahir de Altar a incensalos Sem Trez ductoz; E em que ElRey Mando fazer observar o Ceremonial Romano. [f. 214v-215]

489) Registro da Ordem de Sua Magestade em que manda que todas as I [sic] digo em que manda que as Igrejaz que Sua Excelência Reverendíssima declarava Se podião Cullar [sic] quando Se passasse dellas Provimento Seria com a clauzulla de que Se poderia devedir Sendo necessário [f. 215-215v]

490) Ordem de Sua Magestade Fidelíssima Sobre As conhecenças e dezobrigas dos moradores de Minnas $[s i c]$ na vila de huma Conta que deu a Camera de Villa Rica. <esta ordem esta $>$ [f. 215v]

491) 1747. Ordem porque Sua Magestade Ordena a Sua Excelência Reverendíssima não Concinta na Sua Diocese Sacerdotes alguns naturaes do Reyno, que a [elle] passem Sem emprego Eclesiastico ou Ordena [ilegivel] e mesmos que forem por Cappellaens de navios fazelos transportar. [f. 216-216v]

492) 1757 Ordem pela qual Ordena Sua Magestade a Sua Excelência Reverendíssima lhe informe com o Seu parecer sobre o Requerimento do Reverendo Padre Provincial dos Religiozos Capuchos desta Cidade Sobre Suspender Se a Execução do Breve que alcançarão oz Irmáos, [Beneditinos] da dita Ordem, para terem na Sua Capella Sacrarios, e Torres Com Sinos [f. 216v-217]

493) Ordem [corroído $15 \mathrm{~mm} \times 10 \mathrm{~mm}$ ] Excelência Reverendíssima Remetter a Copia da Resolucao que teve Sendo Bispo de Angola Sobre não Se darem [ductos] á Camera pelo Diacono da Missa Solene. [f. 217]

494) Ordem para Se por em Concurso a Igreja de São João de [ilegivel] pela desistência do Padre Jerônimo Luis Vas e provedor [corroído $30 \mathrm{~mm} \times 10 \mathrm{~mm}$ ], cujo provimento [ilegivel] Mesa da Consciência [f. 217]

495) Ordem para Sua Excelência Reverendíssima proceder contra os Eucesos que fizerem cartas de jogar [f. 218]

496) Carta do Secretário de Estado Francisco Xavier de Mendonça Furtado, Escripta a Sua Excelência Reverendíssima por Ordem de Sua Magestade Fidelíssima de 7 de Outubro de 1767 [f. 218-218v]

497) Ordem de Sua Magestade pela Meza da Consciencia Com a datta de 30 de Dezembro de 1767 [f. 218v-219]

498) Carta de Sua Magestade digo Carta da Meza da Consciencia, Escripta por Ordem de Sua Magestade, a Sua Excelência Reverendíssima com a data de 6 de Junho de 1769 [f. 219-219v] 499) Carta de Sua Magestade escrita a Sua Excelência Reverendíssima pella qual foi servida declarar quais Sáo os Brevez, e rescriptoz e emanados da Curia de Roma que Se com- 
prehendem na Lei de 6 de Maio do anno de 1765, e quais são os que não Se comprehendem, com a data de 23 de Agosto de 1770 [f. 220]

500) Provizão pela Mesa da Conciencia, e Ordenz a Sua Excelência Reverendíssima a favor do Padre Nicolau Teixeira de Carvalho Soutto Maior, e Castro Vigário Colado da Igreja Matris do Senhor Bom Jesus de Anta da Capitania de Goiás, Com data de 21 de Agosto de 1770 anos [f. 220v-221]

501) Carta do Secretario do Estado Martinho de Mello, e Castro escrita a Sua Excelência Reverendíssima por ordem de Sua Magestade a Respeito do Padre Nicolau Teixeira de Carvalho Sotto Maior, e Castro Vigário Collado de Anta, com data de 18 de Dezembro de 1770. [f. 221]

502) Provisão pela Mesa da Consciência, e ordens, pela qual foi Sua Magestade Servido ordenar a Sua Excelência Reverendíssima que o Reverendo Deião da Sé do Rio de Janeiro e Jozé Joaquim Mascarenhas Castello Branco fosse contado nas destribuiçoenz quotidianas, officios etc $\mathrm{Na}$ mesma forma que as maiz dignidades e Cônegos da mesma Sé como abaixo Se declara. < [ilegivel] nela qual Sua Magestade Reverendíssima manda pagar ao Padre Alberto Caetano [ilegivel] [ilegivel] Vigario Colado na Igreja de Nossa Senhora do Pilar do Iguassu Bispado do Rio de Janeiro da [ilegível] da Congrua desde o dia que [Vagou] Igreja do Seu Antecessor the o dia da posse do Suplicante qual ordem a Previzão vai Registada neste [livro] a folha 256> [f. 221-222]

503) Provizão Regia pella Mesa da Consciência e Ordens para Serem os Reverendos Parochoz deste Bispado obrigadoz, á porem Capellaenz nas Capellas Filiaes das Suas Freguesias, que Sua Excelência Reverendíssima lhes designar com a côngrua, que o mesmo Senhor consignar paga pelloz ditoz Reverendos Parochoz. [f. 222-222v]

504) Provizão Regia para Se pôr novamente á Concurso a Igreja de Nossa Senhora do Desterro de Tamby. [f. 222v-224]

505) Provizão Regia para Se pôr novamente a Concurso a Igreja de Nossa Senhora do Pilar de Agoassú. [f. 224-224v]

506) Ordem Regia pelo Tribunal da Meza da Consciência e Ordens para Sua Excelência Reverendíssima Suspender do exercício de Parocho encomendado da Freguesia de Meia Ponte de Goyás ao Padre Manoel da Sylva Campelo na forma, que nella se conthem. [f. 224v]

507) Ordem Regia do Tribunal da Meza da Consciência, e Ordens para Sua Excelência Reverendíssima não Só continuar a Suspensão, que foi posta ao Padre Manoel da Silva Campelo, mas tambem para não consentir que o mesmo Padre Seja Oppositor, ou provido em beneficio algum, ainda por encomendação. [f. 225]

508) Provizão Regia pelo Tribunal da Meza da Consciência, e Ordens em Resposta da Reprezentação, que Sua Excelência Reverendíssima fes para valer a primeira nomeação da Igreja do Pilar do Aguaçú na pessoa do Padre Antonio Jozé Victorino de Souza ordenando Sua Magestade que aos Concursos dos Beneficios deste Bispado só se [corroído $30 \mathrm{~mm} x$ 
$15 \mathrm{~mm}$ ] os naturaes do Ultramar, e só na falta destes os não naturaes na forma abaixo. [f. $225 \mathrm{v}-226]$

509) Provizão Regia pelo Tribunal da Meza da Consciência, e Ordens em Resposta da Reprezentação, que Sua Excelência Reverendíssima fes para valer a primeira nomeação da Igreja de Nossa Senhora do Desterro de Tambi $^{27}$ na pessoa do Padre João Caetano da Fonceca, ordenando Sua Magestade, que aos Concursos dos Beneficios deste Bispado só se adimittão os naturaes do Ultramar, e só na falta destes os não naturaes na forma abaixo. [f. 226-226v]

510) Provizão Regia pelo Tribunal da Meza da Consciência, e Ordens em Rezolução da Conta que Sua Excelência Reverendíssima deo da Sentença proferida contra o Padre Antonio José Malheiro Conselheiro Cura da Sé deste Bispado de privação do dito Beneficio; ordenando Sua Magestade, que Se verifique a dita Sentença na Igreja de São Jozé de Tocantis, que lhe ficou pertencendo pela permuta, que fes com o Padre Roberto Carvalho Ribeiro de Bustamante, julgando-se vaga a dita Igreja e pondo-se a Concurso na forma abaixo. [f. 226v-227]

511) Provizam [corroido $20 m m \times 5 \mathrm{~mm}$ ] Sua Magestade há por bem, que os Capitularez da Sé dezta Cidade do Ryo de Janeiro, prezentez, venção peloz auzentez os Ordenadoz, e benezez que que lhes tocão heztocáo, e que as Congruaz de todoz os Beneficioz della Se entreguem a Seu Priozte assim os que Se vencerem, como os que eztiverem vencidoz, desde que dezde que houve Corpo Corpo [sic] de Cabido na mesma Sé = 20 de Outubro de 1688 [f. 227v]

512) Provizam porque Sua Magestade há por bem Conceder ao Cabido dezta Capitania do Ryo de Janeiro [corroído $40 \mathrm{~mm} \times 10 \mathrm{~mm}$ ] Vacante, que o seu Meyrinho possa usar de $=$ Vara branca $=$ de 26 de Novembro de 1700 [f. 228]

513) Provizam porque Sua Magestade há por bem mandar, que os 120 réis que Se dão ao Prelado para os Ordenadoz do Seu Vigário Geral, e Provizor 60 réis a Cada hum oz faça entregar aoz taez Officiaez, havendo oz, e que oz 80 réis dos pobrez oz mande entregar a pessoa que o Cabido eleger para [remetter] [f. 228-228v]

514) Registo da Carta Regia, em que Sua Magestade, que Deus Guarde remeteo ao Excelentíssimo e Reverendíssimo Senhor Bispo deste Bispado os Exemplares da Bulla porque o Ilustríssimo Padre Clemente XIV Supprimio, e extinguio a Companhia chamada de Jezus. E da Real Ley, porque Sua Magestade foi Servido acordar o Seu Real Beneplacito para a execução da mesma Bulla recomendando e ordenando o dito Excelentíssimo e Reverendíssimo Senhor Bispo o que Se mostra da mesma carta. [f. 228v-229]

515) Registo da Real Ley, porque Sua Magestade foi Servido acordar o Seu Real Beneplacito para a execução da mesma Bulla. [f. 229-231]

516) Copia do Breve do Ilustríssimo Padre Clemente XIV, pelo qual a Sociedade chamada de Jezus Se extingue, e suprime em todo o Orbe [f. 231v-245]

\footnotetext{
${ }^{27}$ É comum o uso Nossa Senhora do Desterro de Tambi para a localidade Itambi.
} 
517) Registo da Ordem de Sua Magestade Fidelíssima pela Sua Secretaria de Estado para Sua Excelência Reverendíssima fazer guardar em cofre de tres chaves a Colleção authentica dos Breves Pontificiaz, Leys Regiaz, Instruçoenz na forma abaixo. [f. 245-245v]

518) Registo da Ordem Regia pela Secretaria de Estado para Sua Excelência Reverendíssima fazer guardar em Cofre de Tres Chaves o Supplemento, e Appendix, que abaixo se vé na mesma Ordem. [f. 245v]

519) Ordem Regia pela Secretaria de Estado para Sua Excelência Reverendíssima mandar guardar no Cofre de Tres Chaves a colleção [presta] e authentica; e o maiz, que da mesma [corroído $15 \mathrm{~mm} \times 10 \mathrm{~mm}$ ] se mostra. [f. 246]

520) Ordem Regia pela Secretaria de Estado para Sua Excelência Reverendíssima mandar guardar em Cofre de Tres Chaves a Deduçáo Chronologica, e Analytica, e o mais, que da mesma ordem Se mostra. [f. 246v]

521) Ordem pela Secretaria de Estado para Sua Excelência Reverendíssima fazer Recolher no Cofre de Tres Chaves a segunda parte da Dedução Chronologica. [f. 247]

522) Lembrança, que veio dentro da Ordem acima, ou atraz; digo, da Ordem acima. [f. 247]

523) Registo de Provisão porque foi Sua Magestade que Deos guarde Servido Confirmar a Remisão do foro de dezeseis tostoenz, que Se achava imposto nos chãos que Comprou o Ilustrissimo Bispo a Inacio Alvares para fundar hum Aljube; Com declaração que só terá Lugar em quanto aquela Caza servir de Aljube, porque Reduzindo-se a outro uzo pagará o foro que lhe foi imposto. [f. 247v-248]

524) Faculdade, que Magestade Fidelíssima foi servido conceder maiz hum ano ao Reverendo Conego Antonio de Gouvea Pinto para poder eztar na Corte, afim de usar dos banhos das Caldaz pelas queixas que tem, na forma abaixo. [f. 248v]

525) Carta do Illustríssimo Senhor José de Seabra da Sylva para Sua Excelência Reverendíssima poder ordenar a José Joaquim de Azevedo Coutinho [f. 249]

526) Carta do Ilustríssimo Senhor Jozé de Seabra da Sylva para Sua Excelência Reverendíssima poder ordenar a Francisco Dias Pereira. [f. 249-249v]

527) Carta do Ilustríssimo Senhor José de Seabra da Sylva para Sua Excelência Reverendíssima poder Ordenar a Manoel Ferreira de Oliveira [f. 249v]

528) Carta do Ilustríssimo Senhor José de Seabra da Sylva para Sua Excelência Reverendíssima poder ordenar a João Damasceno Ferreira [f. 250]

529) Carta do Ilustríssimo Senhor Martinho de Mello, e Castro para Sua Excelência poder Ordenar a Juliáo Francisco Xavier. [f. 250]

530) Carta do Ilustríssimo Senhor Jozé de Seabra e Sylva para Sua Excelência poder Ordenar a Lourenço Ferraz Santiago. [f. 250v]

531) Avizo de 15 de Janeiro de 1788 em que Sua Magestade Ordena ao Excelentíssimo e Reverendíssimo Senhor Bispo mande conservar no Recolhimento de Nossa Senhora do Parto a Maria Francisca Capistrana mulher de João Antunes de Andrade [f. 250v-256] 
532) Avizo da Secretaria de Estado de 28 de Julho de 1790 para ser conservada no Recolhemento [sic] de Nossa Senhora do Parto Dona Francizca Thereza da Costa mulher do Capitam João Gomes Aranha. [f. 256-256v]

533) Provisam pela qual Sua Magestade Fidelíssima mandar pagar ao Padre Alberto Caetano Alvez de Barroz Vigário Colado na Igreja de Nossa Senhora do Pillar do Aguassú Bispado do Ryo de Janeiro, duas partes da Congrua dezde o dia que vagou a Igreja do Seu antecessor the [o dia] a posse do mesmo [f. 256v-257]

534) Alvará de Sua Magestade Fidelíssima pelo qual ha por bem tomar a final e deciziva determinação sobre as contendas de Jurisdição entre os Regulares e Senhores Bispoz Ultramarinos, a qual participa ao Excelentíssimo e Reverendíssimo Senhor Bispo do Rio de Janeiro [f. 257-258]

535) Copia de huma petição e Certidáo da Provisão Regia, pela qual se desanexou da freguezia de Guapymerim a Fazenda de Joze Roiz de Avelar, e ficou anexada a Freguezia de Magé [f. 258v-259]

536) Ordem de Sua Alteza Real pela qual ordena [corroído $39 m m \times 15 \mathrm{~mm}$ ] hum só Candidato para Cada Igreja Parochial [f. 259]

537) Copia do Avizo da Secretaria de Estado pelo qual Se concedeo licença ao Capitam Joze Joaquim Pereira residente na Vila de Sam Salvador dos Campos para [edificar] a Capella de Santa Rita que tem na sua Fazenda denominada Santa Cruz [f. 259v]

538) Copia de hum officio do Illustríssimo e Reverendíssimo Senhor Conde dos Arcos Vice Rey [corroído $10 \mathrm{~mm} \times 10 \mathrm{~mm}$ ] Estado do Brazil dirigido ao Illustríssimo e Reverendíssimo Senhor Cabbido, Sede Vacante com huma Supplica feita a Sua Alteza Real pelo Excelentíssimo Reverendíssimo Prelado de Goyáz para cessar toda a Jurisdição naquelle Território de Goyáz logo que della tomasse posse o Ilustríssimo Reverendíssimo Prelado; tudo na forma seguinte [f. 259v-260]

539) Licença Regia concedida ao Senhor Gregorio Francisco de Miranda residente nos [corroído $30 \mathrm{~mm} \times 15 \mathrm{~mm}$ ] para erigir huma Capella na sua Fazenda com a Invocação Nossa Senhora d'Abadia [f. 260-260v]

540) Ordem de Sua Alteza Real pela Meza da Consciencia e Ordens com data de 23 de Janeiro de 1807 anos pela qual na falta, ou ausencia dos Excelentíssimos e Reverendíssimos Prelados desta Dioceze fica pertecendo ao Illustríssimo Cabbido a, Faculdade de fazer Concursos, e Propostas das Dignidades, Conezias, ou outros quaesquer Benificios Ecclesiasticos com Cura, ou sem cura de almas [f. 260v-261]

541) Ordem de Sual Alteza Real pelo Conselho Ultramarino com data de 3 de Abril de 1807, pela qual manda, que se profane, e devasse o Cemiterio da Capella de São Domingos nesta Cidade [f. 261-261v]

542) Decreto <Carta Régia > por que Sua Alteza Real permitte, que o Reverendo Manoel da Cunha de Carvalho, Vigario da Vara da Villa de Ilha Grande uze das Insígnias, e dos Privilegios de Conego, com data de 18 de Julho de 1808 anos [f. 262] 
543) Decreto <Carta [ilegivel] $>$, porque Sua Alteza Real permitte o uzo de annel e Solideo aos Reverendos Capelláes dos Regimentos da Linha da [corroído $55 \mathrm{~mm} \times 7 \mathrm{~mm}$ ] desta Corte do Rio de Janeiro [f. 262]

544) Alvara, porque Sua Alteza Real condecora a Sé Cathedral desta Cidade do Rio de Janeiro com o Titulo e Dignidade de Capella Real. Transferindo-a para a Igreja contigua ao seo Real Palacio, e dá outras providencias, na forma seguinte [f. 262-263v]

545) Alvara porque Sua Alteza Real Ha por bem desannexar da Freguezia de São Joze desta Cidade as Povoaçoens do Botafogo, Praia vermelha, e Tejuca creando dellas a nova Freguesia de São João [f. 263v-263]

546) Carta Regia, pela qual Sual Alteza Real o Princepe Regente Nosso Senhor Ha por bem nomear seo Capelláo Mor ao Excelentíssimo e Reverendíssimo Senhor Bispo desta Diocese Dom Joze Caetano da Silva Coutinho [f. 263v-264v]

547) Alvará porque Sua Alteza Real ha por bem desannexar da Freguezia de Nossa Senhora do Desterro em a Ilha de Santa Catharina o Território denominado Ribeirao, Creando nelle a nova Freguesia de Nossa Senhora da Lapa, como nelle se declara [f. 264v-266]

548) Traslado da Escriptura da Devizão, e Limites da nova Freguesia mencionada no Alvará acima. [f. 266v-267]

549) Provisam Regia dirigida pelo Conselho Ultramarino para que so conservem as Ordens Terceiras de Nossa Senhora do Carmo e de São Francisco estabelecidas na Vila de São Salvador dos Campos pro interim na fruição de fazerem as Funçôes, Officios, e Exercícios Espirituaes da sua Regra, e Estatutos sem intervenção alguma do Parocho local, na forma abaixo declarada. [f. 267v-268] 